\title{
HALLÂC'IN MAHKEME SÜRECI VE KATLINE FETVÂ VERENLER
}

Eyyup AKDAC̆ ${ }^{*}$

\section{Makale Bilgisi}

Makale Türü: Araştırma Makalesi, Geliş Tarihi: 17 Mayıs 2020, Kabul Tarihi: 17 Eylül 2020, Yayın Tarihi: 30 Eylül 2020, Atıf: Akdağ, Eyyup. “Hallâc'ın Mahkeme Süreci ve Katline Fetvâ Verenler". Dinbilimleri Akademik Araştırma Dergisi 20/2 (Eylül 2020): 1167-1194.

https://doi.org/10.33415/daad.738648

\section{Article Information}

Article Types: Research Article, Received: 17 May 2020, Accepted: 17 September 2020, Published: 30 September 2020, Cite as: Akdağ, Eyyup. "The Court Process of Hallac and Those Who Gave Fatwa of the Death Penalty". Journal of Academic Research in Religious Sciences 20/2 (September 2020): 1167-1194.

https://doi.org/10.33415/daad.738648

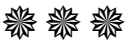

öz

\begin{abstract}
Tasavvuf tarihinin önemli isimlerinden birisi olan Hallâc, fikir ve düşünceleriyle tarihî süreç boyunca hep canlı kalmıştır. Tarihî süreçte Hallâc'ın fikir ve düşüncelerini, hâl ve sözlerini destekleyip savunanlar olduğu gibi bunlara karşı çıkan, aşııı tepki gösteren ve sert eleştiri yöneltenler de hep olmuştur. Bu iki yaklaşımın dışında bazıları ise kesin bir görüş belirtmeyerek sükûtu intiyar etmiştir. Hallâc, Abbâsî iktidarında söz ve eylemlerinden dolayı uzun süre, müteaddit olarak sorgulanmış ve mahkeme edilmiştir. Hallâc'a sorguda Karâmita davetçisi olma suçlaması yöneltildiği gibi hulûl, ittihat, rubûbiyyet, Kur'ân'ı tahkîr ve şeri'atın emirlerini tahrif gibi bazı suçlamalar da yöneltilmiştir. Nihâî mahkemede ulemânın ittifak ve icmâsıyle katline fetvâ verilmiş ve karar da o şekilde infaz edilmiştir. Abbasî halifesi Muktedir-Billâh'ın veziri Hâmid b. el-'Abbâs'ın idam kararının alınmasında ısrarı, baskısı ve yönlendirmesi olmuştur. Hallâc'ın görüş, düşünce ve sözlerinin ayrıntılı olarak irdelenmesi bu makalenin konusu değildir. Bu makale esas olarak Hallâc'ın hayatıyla beraber sorgulandığı ve mahkeme edildiği süreçleri, kendisine yöneltilen suçlamaları ve katline fetvâ veren kadı ve ulemâları konu edinmektedir. Hallâc'ın idamı konusunda ulemânın ittifak ve icmâsından bahsedilmektedir. Ulemânın ittifak ve icmâsının hakikatte var olup olmadığı da bu makalede ayrıca sorgulanacaktır.
\end{abstract}

Anahtar Kelimeler: Tasavvuf, Hallâc, Mahkeme süreci, Fetvâ, Küfür, Katl.

Dr. Öğr. Üyesi, Kastamonu Üniversitesi, İlahiyat Fakültesi, Tasavvuf Anabilim Dalı, eyyupakdag5@hotmail.com, Orcid Id: https://orcid.org/0000-0002-1173-323X 
Hallac, one of the important names in the history of Sufism, has always remained alive throughout the historical process with its ideas and thoughts. In the historical process, there were always those who supported and defended Hallac's ideas and thoughts, doings, and words, as well as those who opposed, overreacted, and directed harsh criticism. Apart from these two approaches, some of them kept silent, without specifying an exact opinion. Hallac went on trial and was questioned frequently for a long time due to his words and actions in the Abbasi reign. In his interrogation, the accusation of being inviter of Karamite was directed against Hallac, as well as some accusations such as integration (hulul), unification (ittihat), nursing (rububbiyyet), insulting the Qur'an, and falsification of the orders of the Sharia. In the final court, fatwa of the death penalty was given with the alliance and consensus of the ulama, and the decision was executed in that way. Hamid b. al-'Abbas, who is the vizier of Abbasid caliph MuqtaBillah, insisted, directed, and had influence over that the death penalty must be given. The examination of the views, thoughts, and words of Hallac is not the subject of this article. Besides his life, this article mainly focuses on the processes during which Hallac was questioned and trialed, the accusations directed against him, and the judges and ulamas who gave fatwa of his death penalty. The alliance and consensus of the ulama in the execution of Hallac are talked about. Whether the alliance and consensus of the ulama exist is to be questioned separately in this article.

Keywords: Sufism, Hallac, Court process, Fatwa, Profanity, Slaughter.

\section{Giriş}

İslâm düşünce tarihinde adından en çok söz ettiren, lehte ve aleyhte en çok söz söylenen şahısların başında Hallâc gelmektedir. Hallâc hakkında tarihî süreçte birçok zıt görüş ve kanaatlar serdedilmiştir. Kimileri Hallâc'ı sihirbaz, sahtekâr, mecnûn, hulûl ve ittihâta kâil, kâfir ve zındık bir şahıs olarak itham ederken kimileri de aynı şahsı kerâmet sahibi, Allah âşıkı, Allah şehidi, muvahhitlerin imamı olarak taltif etmiştir. ${ }^{1}$

Hallâc hakkında zıt düşünce ve kanaatlar, Hallâc'ın bizzat kendi yaşadığı zamanda başlamış ve günümüze kadar devam etmiştir. Hallâc'ı zındık ve küfürle ilk olarak itham eden şahıslardan birisi Hallâc'ın kayın-

1 Ebû Bekir Ahmed b. Ali el-Hatîb el-Bağdâdî, Târîhu Bă̆dâd, thk. Beşşâr 'Avvâd Ma'rûf (Beyrût: Dârü'l-ğarbi'l-İslâmî, 1422/2002), 8/699; Salâhaddîn Halîl es-Safedî, el-Vâfí bi'l-vefeyât, thk. Ahmed el-Arnavud, Türkî Mustafa (Beyrût: Dâru ihyâi't-türâs, 1420/2000), 13/46; Ebu'l-Abbâs Şemsüddîn Ahmed b. Muhammed b. Hallikân, Vefayâtü'l-ayân ve enbâu ebnâi'z-zamân, nşr. İhsân Abbâs (Beyrut: Dâru Sâdır, 1994), 2/141; Ebû Abdillâh Şemsüddîn Muhammed b. Ahmed ez- Zehebî, Siyeru a'lâmi'lnübelâ (Kâhire: Dâru'l-hadîs, 1427/2006), 11/194-205; Ebü'l-Fadl Ahmed b. Ali İbn Hacer el-'Askalânî, Lisânü'l-mîzân, nşr. Abdülfettah Ebû Ğudde (Dımaşk: Dârü'lbeşâiri'l-İslâmiyye, 2002), 3/211; Zeynüddîn Ömer b. Muzaffer b. Verdî, Târîhu İbnü'l-Verdî (Beyrût: Dârü'l-kütübi'l-ilmiyye, 1417/1996), 1/247-248; Ebû'l-Fidâ İsmail b. Ömer İbn Kesîr, el-Bidâye ve'n-nihâye, nşr. Abdullah b. Abdulmuhsin et-Türkî (Kâhire: Dâru hecr, 1418/1997), 14/819. 
pederi Şeyh Ebû Yakub el-Akta' diğeri ise üstadı Ebû Abdullah 'Amr b. Osman el-Mekkî'dir (ö. 297/910). Ebû Yakub el-Akta', ilk zamanlar zühd üzere gördüğü ve bu sebepten dolayı kızını nikâhladığı Hallâc'ı daha sonraki zamanlarda söz ve davranışlarından dolayı sihir, küfür ve zındıklıkla itham etmiştir. Aynı şekilde 'Amr b. Osman el-Mekkî de ilk zamanlar tasavvuf hırkasını kendi eliyle giydirdiği müridi Hallâc'ı daha sonraki zamanlarda aynı şekilde suçlamıştır. ${ }^{2}$ Ebû Yakub el-Akta' ve 'Amr b. Osman ile başlayan bu sürece daha sonraki zamanlarda birçok isim katılmıştır. 0 isimlerden birisi de ibn Teymiyye'dir (ö. 728/1328). İbn Teymiyye de aynı kanaatı devam ettirerek Hallâc'ı küfür ve zındıklıkla itham etmiştir. ${ }^{3}$

Bu menfi görüş ve yaklaşımlara karşı, Hallâc'a tazimde aşırı giden ve onu velayetin zirvesinde gören diğer bir yaklaşım tarzı da varlığını günümüze kadar hep sürdürmüştür. Bu yaklaşımın öncüleri arasında Ebü'l'Abbâs b. 'Atâ (ö. 309/922), Ebû Abdullah Muhammed b. Hafîf (ö. 371/982) ve Ebü'l-Kâsım İbrahîm b. Muhammed en-Nasrâbâdî'nin (ö. 367/978) adlarını zikretmek gerekir. Hallâc'a mülâki olmuş bu üç şahıs, Hallâc'ın hâl ve kavillerini doğru bulmuş ve onu fazilet ölçüsünde üst makamda görmüşlerdir. Bu manada Nasrâbâdî'nin şu sözü dikkat çekicidir: 'Eğer nebî ve sıddîklardan sonra bir muvahhid gelecek olsa idi, o şahıs muhakkak Hallâc olurdu. ${ }^{4}$ Muhammed b. Hafîf de: 'Hüseyin b. Mansûr rabbânî bir âlimdir', ${ }^{5}$ diyerek benzer kanaatını ifade etmiştir.

Tarihi süreçte Kerbelâ şehidi Hz. Hüseyin'in (ö. 61/680) kanı mı yoksa Hallâc'ın kanı mı daha faziletli tartışması bile yapılmıştır. Hallâc taraftarları, Hallâc'ın kanının yeryüzüne döküldüğünde 'Allah, Allah' şeklinde yazıya dönüştüğünü iddia ederek Hâllâc'ın kanının Hz. Hüseyin'in kanından daha faziletli olduğunu iddia etmişlerdir. ${ }^{6}$ Meşhur müellif Zehebî (ö. 748/1348) bu tartışmaya katılarak Hallâc'ın, Hz. Hüseyin ile mukayese

2 Ebû Mansûr Abdülkâhir b. Tâhir el-Bağdâdî, el-Fark beyne'l-firak ve beyânü'l-firkati'tnâciye (Beyrût: Dârü'l-âfâkı'l-cedîde, 1977), 246-248; Ebü'l-Ferec Abdurrahman b. Ali İbnü'l-Cevzî, Telbîsü İblîs (Lübnân: Dârü'l-fikir, 1421/2001), 153; Zehebî, Siyeru a'lâmi'l-nübelâ, 11/, 195, 204; 'Askalânî, Lisânü'l-mîzân, 3/211.

3 Ebü'l-Ferec Cemâleddin Abdurrahmân b. Ali İbnü'l-Cevzî, el-Muntazam fî târîhi'lümemi ve'l-mülûk, nşr. Muhammed Abdülkadir 'Atâ ve Mustafa Abdülkadir 'Atâ (Beyrût: Dâru'l-kütübi'l-ilmiye, 412/1992), 13/203; Ebû'l-'Abbâs Takıyüddîn Ahmed b. Abdülhalîm İbn Teymiyye, el-Fetâvâ el-Kübrâ, thk. Muhammed Abdülkâdir 'Atâ, Mustafa Abdülkâdir 'Atâ (Beyrût: Dârü'l-kütübi'l-ilmiyye, 408/1987), 3/480.

4 Bağdâdî, Târîhu Bağdâd, 8/699; İbnü'l-Cevzî, Telbîsü İblîs, 155.

5 Ebû Abdurrahmân Muhammed b. el-Hüseyin es-Sülemî, Tabakâtü’s-sûfiyye, thk. Nûreddîn Şûreybe (Kâhire: Mektebetü'l-Hâncî, 1434/2014), 308; Zehebî, Siyeru a'lâmi'l-nübelâ, 11/194; İbn Kesîr, el-Bidâye ve’n-nihâye, 14/819.

6 Bahâeddîn Muhammed b. Hüseyin el-Ấmilî, el-Keşkûl, thk. Muhammed Abdülkerîm en-Nemirî (Beyrût: Dârü'l-kütübi'l-ilmiyye, 1418/1998), 2/220. 
edilmesini uygun görmediğini ifade etmiştir. Zehebî’ye göre; ‘Hz. Hüseyin şer ehli kimselerin kılıçlarıyla öldürülmüş bir Allah şehidi iken Hallâc ise küfür ve zındıklığı sebebiyle şeri'at ehli kimselerin kılıcıyla öldürülmüş bir kâfirdir. ${ }^{7}$

Aynı tartışmaya katılan ibn Teymiyye de Hallâc'ın katlinde yere düşen kanının Allah ismini yazdı gibi keramet türü bütün nakillerin yalan olduğunu ifade etmiştir. İbn Teymiyye'nin beyanına göre tarihte birçok peygamber ve onların birçok ashabı öldürüldüğü halde onlardan dökülen hiçbir kan Allah şeklinde bir yazıya dönüşmemiştir. Hallâc bu insanlardan daha mı hayırlıdır? Sorusunu yönelten İbn Teymiyye; kanın necis olduğuna da dikkat çekerek necis bir şeyin Allah ismini yazmasının caiz olmadığını ayrıca belirtmiştir. ${ }^{8}$

Kelam ve fıkıh ulemâsı genel olarak Hallâc'a hulûl ve ittihât suçlaması yönelterek onun kâfir ve zındık olduğunu ifade etmişlerdir. Sûfîlerin Hallâc konusundaki görüşleri ise muhteliftir. Bir kısım sûfî, Hallâc'ı kendilerinden kabul edip söz, hâl ve davranışlarını tasvib ederken diğer bir çoğunluk ise Hallâc'ı kendilerinden kabul etmemiş, söz, hâl ve davranışlarını da doğru bulmamışlardır. ${ }^{9}$ Hücvirî (ö. 465/1072) Keşfu'l-mahcûb adlı eserinde önceki sûfîlerin aksine sonraki sûfîlerin genel olarak Hallâc'ı kendilerinden kabul ettiklerini, hâl ve sözlerini doğru bulduklarını beyan etmiştir. Hücvirî̀ye göre önceki sûfîler, Hallâc'ı hâl ve itikadından dolayı değil, hâl ve itikadını izhar ediş biçimini kötü gördüklerinden dolayı reddetmişlerdir. ${ }^{10}$ Bu manada Ebû Saîd Ebü'l-Hayr (ö. 440/1049) ve Ebü'lKâsım Abdullah el-Kürrekânî (ö. 450/1058) gibi önemli sûfî şahıslar Hallâc'a büyük değer vermişler ve: "Doğu ve batıda onun gibisi yoktur" diyerek bu saygıyı ifade etmişlerdir. ${ }^{11}$

Hallâc'ın vefatından sonra Hallâc taraftarı olduğunu iddia eden fırka ve gruplar ortaya çıkmıştır. Abdülkâhir el-Bağdâdî (ö. 429/1037-38) el-

7 Zehebî, Siyeru a lâmi'l-nübelâ, 15/468.

8 Ebû'l-'Abbâs Takıyüddîn Ahmed b. Abdülhalîm İbn Teymiyye, Mecmû'u'l-fetâvâ, nşr. Enver el-Bâz, 'Âmir el-Cezzâr (Mısır: Dârü'l-Vefâ, 1426/2005), 2/483-485; İbn Teymiyye, el-Fetâvâ el-Kübrâ, 3/481.

9 Sülemî, Tabakâtü's-sûfiyye, 307; Bağdâdî, Târîhu Bağdâd, 8/689; Ebû Saî̂d Abdülkerîm b. Muhammed b. Mansûr et-Temîmî es-Sem'ânî, el-Ensâb, nşr. Abdurrahmân b. Yahyâ (Haydarâbâd: Meclis-i dâireti'l-meârifi'l-Osmâniyyi, 1382/1962), 4/315; İbn Hallikân, Vefayâtü'l-ayân, 2/141; Abdurrahman Câmî, Nefahâtü'l-üns, trc. Lâmiî Çelebi, nşr. Süleyman Uludă̆, Mustafa Kara (İstanbul: Marifet Yayınları, 2008), 290294.

10 Ali b. Osman Cüllâbî el-Hücvirî, Keş̧fu'l-mahcûb Hakikat Bilgisi, nşr. Süleyman Uludağ (İstanbul: Dergâh Yayınları, 2010), 212-214.

11 Hücvirî, Keş̧fu'l-mahcûb, 213; Câmî, Nefahâtü'l-üns, 291. 
Fark beyne'l-fırak adlı eserinde 'Hulûliyye' mezhebinin on kısım olduğunu ve bu on kısımdan birisinin de Hüseyin b. Mansûr'a nisbet edilen 'Hallâciyye' fırkası olduğunu beyan etmektedir. ${ }^{12}$ Ebû Ali et-Tenûhî (ö. 384/994) de Nişvârü'l-muhâdara adlı eserinde Hallâciyye mensuplarının Lâhût'un insana hulûl ettiğine itikat ettikleri gibi Hz. Peygamber'in (a.s.) ruhunun da Ebû 'Imâre Muhammed b. Abdullah isminde bir şahsa hulûl ettiğine ve bu şahsın da Hz. Peygamber (a.s.) adına konuştuğuna inandıklarını beyan etmektedir. ${ }^{13}$ Hücvirî ise bu fırka mensuplarını mülhid olarak değerlendirmiş ve bu kimselerin Hallâc'ın fikirleriyle uzaktan ve yakından hiçbir ilişkilerinin olmadığını ifade etmiştir. Hücvirî’ye göre Hallâc'a bağlılık davasında bulunan bu insanlar, Hallâc'ın sözlerini kendi zındık düşüncelerine delil kılmışlar ve kendilerine 'Hallâciyye' olarak isim vermişlerdir. ${ }^{14}$

\section{Hallâc'ın Hayatı}

Kaynaklarda adı, el-Hüseyin b. Mansûr b. Mahmî, künyesi, Ebû Muğîs ve Ebû Abdullah nisbesi ise, el-Fârîsi, el-Beydâvî, es-Sûfî şeklinde geçmektedir. Babasının pamuk atma mesleğine nispetle veya insanların sırlarını açığa çıkarması sebebiyle, الحلاج 'el-Hâllâc' ismi ile lakaplanmıştır. Daha çok tanınması ve şöhreti bu lakabıyla olmuştur. ${ }^{15}$

Hallâc, 244/858 yılında İran'ın büyük şehirlerinden Beydâ'nın kuzey doğusunda kalan Tûr nahiyesinde doğmuştur. Dedesi mecûsî olan ${ }^{16}$ Hallâc ilk eğitimine Irak Vâsıt'ta başlamıştır. Babası tarafından Vâsıt'a getirilen Hallâc burada Kur'ân kıraatı ve kavâid dersleri almıştır. Vâsıt'taki eğitimini tamamlayan Hallâc on altı yaşında Tüster şehrine gelmiştir. Burada 260-262/873-875 yıllar arası iki yıl boyunca Sehl b. Abdullah etTüsterî́nin (ö. 283/896) yanında kalmış, onun ilim ve manevî neşvesinden istifade etmiştir. Tüsterî̀nin önde gelen müridleri arasına dâhil olan

12 Bağdâdî, el-Fark beyne'l-firak, 246.

13 Ebû Ali el-Muhassin b. Ali el-Kâdî et-Tenûhî, Nişvârü'l-muhâdara ve ahbâru'lmüzâkere, thk. Abbûd es-Sâlucî (Beyrût: Dâru Sâdır, 1995), 1/173.

14 Hücvirî, Keşfu'l-mahcûb, 213;

15 Sülemî, Tabakâtü's-sûfiyye, 307; Ebü'l-Ferec Muhammed b. İshâk İbnü'n-Nedîm, elFihrist, thk. İbrâhim Ramazân (Beyrût: Dârü'l-ma'rife, 1417/1997), 236; Bağdâdî, Târîhu Bă̆dâd, 8/688-689; Bağdâdî, el-Fark beyne’l-firak, 246; Sem‘ânî, el-Ensâb, 4/314; Ebü'l-Hasen Ali b. Ebî'l-Kerem el-Cezerî İbnü'l-Esîr, el-Lübâb fî tehzîbi'l-ensâb (Beyrût: Dâru Sâdır, 1400/1980), 1/403; Ali b. Enceb el-Bağdâdî es-Sấî, Ahbâru'lHallâc, thk. Muvaffik Fevzî el-Ceber (Dımeşk: Dârü’t-talî‘ati'l-cedîde, 1997), 22; İbn Hallikân, Vefayâtü'l-a'yân, 2/140; Safedî, el-Vâfî bi'l-vefeyât, 13/46; Zehebî, Siyeru a'lâmi'l-nübelâ, 11/194; İbn Kesîr, el-Bidâye ve'n-nihâye, 14/818-820.

16 Sem'ânî, el-Ensâb, 4/314; İbnü'l-Esîr, el-Lübâb, 1/403; Sâî̀, Ahbâru'l-Hallâc, 22; Zehebî, Siyeru a'lâmi'l-nübelâ, 11/194. 
Hallâc, üstadının yanında mümkün mertebe münâkaşa ve cedelden uzak bir eğitim hayatı geçirmiştir. ${ }^{17}$

Hallâc on sekiz yaşında Tüster'den Basra'ya gelmiştir. Burada hayatında önemli bir rol oynayan 'Amr b. Osman el-Mekkî ile tanışmış ve ona mürid olmuştur. Hallâc 'Amr b. Osman'ın yanında on sekiz ay kalmış ve onun elinden tarikat hırkasını giymiştir. Hallâc, Basra'da 'Amr b. Osman dışında bir başka sufî Ebû Yakub el-Akta' el-Basrî ile tanışmıştır. Ebû Yakub'un güvenini kazanan Hallâc 263/876 yııının sonlarına doğru üstadının kızıyla da evlenmiştir. ${ }^{18}$

264/877 yılında yirmi yaşında Bağdat'a gelen Hallâc, burada Ebü'lKâsım Cüneyd-i Bağdâdî (ö. 297/909) ile Ebü'l-Hüseyin en-Nûrî’nin (ö. 295/908) meclislerine katılmış ve Cüneyd'den de tarikat hırkası giymiştir. Daha sonraki süreçte Hallâc, üstadları Cüneyd ve 'Amr b. Osman'a tepki göstererek onların eliyle giydiği tarikat hırkalarını çıkarmışıır. ${ }^{19}$

272/886 yılında ilk haccını yapan Hallâc, bir sene kaldığı Mekke'de yoğun bir ibadet hayatı geçirmiştir. Bu süre zarfında çok sayıda taraftar edinen Hallâc Mekke'den büyük bir sûfî topluluğuyla Bağdat'a geri dönmüştür. Bağdat, Hallâc için sorunların başladığı ilk yer olmuştur. Burada Hallâc'a ilk tepkiyi Cüneyd-i Bağdâdî göstermiştir. Hallâc'ın davranışlarından ve kendisine yönelttiği sorulardan rahatsızlık duyan Cüneyd, Hallâc'। 'iddiâ' ve 'bid'at' ehli olmakla itham etmiş ve: 'Kanın hangi darağacını ıslatacak' diyerek ileride vukû bulacak olaylara ait bir öngörüde bulunmuştur. ${ }^{20}$ Cüneyd'in bu ithamından sonra yalnızlık hisseden Hallâc burada daha fazla kalamayacağını anlamış, eşini yanına alarak Tüster'e dönmüştür. Bağdat aksine, bir yıl kaldığı Tüster, Hallâc'ın halk tarafından büyük bir hüsn-i kabul gördüğü bir şehir olmuştur. ${ }^{21}$

17 Sem'ânî, el-Ensâb, 4/314-316; Sâî̂, Ahbâru'l-Hallâc, 23; Zehebî, Siyeru a'lâmi'lnübelâ, 11/194; İbn Kesîr, el-Bidâye ve'n-nihâye, 14/818-820; Louis Massignon, İslâm'ın Mistik Şehidi Hallâc-ı Mansûr'un Çilesi, trc. İsmet Birkan (Ankara: Ardıç Yayınları, 2006), 1/55-57; Süleyman Uludağ, "Hallâc-1 Mansûr", Türkiye Diyanet Vakfi İslâm Ansiklopedisi (İstanbul: TDV Yayınları, 1997), 15/377-381.

18 Bağdâdî, Târîhu Bağdâd, 8/689-699; Sem'ânî, el-Ensâb, 4/314-316; Sâî̀, Ahbâru’Hallâc, 25; Zehebî, Siyeru a'lâmi'l-nübelâ, 11/194.

19 Sülemî, Tabakâtü's-sûfiyye, 307; Bağdâdî, Târîhu Bağdâd, 8/688-689; İbnü'l-Esîr, elLübâb, 1/403; Sâî̀, Ahbâru'l-Hallâc, 25; İbn Kesîr, el-Bidâye ve'n-nihâye, 14/819; Zehebî, Siyeru a'lâmi'l-nübelâ, 11/194.

20 Bağdâdî, Târîhu Bağdâd, 8/690; Sem‘ânî, el-Ensâb, 4/316; Zehebî, Siyeru a'lâmi'lnübelâ, 11/195-196.

21 Bağdâdî, Târîhu Bağdâd, 8/689; Sem‘ânî, el-Ensâb, 4/316. 
Oğlu Hamd'ın bildirdiğine göre Hallâc, Tüster'de âilesinden 274279/887-892 yıllar arası beş yıl uzaklaşmıştır. Bu süre zarfında Hallâc; Horasan, Maverâünnehir, Kirmân ve Sicistân bölgelerini dolaşmış ve daha sonra da Fâris'e dönmüştür. Fâris'te meclisler tanzim ederek insanları Allah'a davet etmeye başlayan Hallâc, burada Ebû Abdullah ez-Zâhid olarak tanınmıştır. Daha sonra Ehvâz'a geçen Hallâc, Ehvâz'da da Fâris'te olduğu gibi halkın ve ulemânın teveccühünü kazanmıştır. Burada insanların kalplerinden geçirdikleri sırları ifşâ eden Hallâc'a حلاج الأسرار 'Hallâcü'l-esrâr' denmiştir. ${ }^{22}$

Ehvâz'dan sonra Basra'ya gelen Hallâc burada az bir süre kalmıştır. ${ }^{23}$ Basra'dan mürîdan ve talebelerinden oluşan büyük bir kalabalıkla 281/894 yıında ikinci haccını yapmak için Mekke'ye gitmiştir. Burada önemli bir sûfî şahsiyet Ebû Yakub en-Nehracûrî'nin (ö. 330/941) tepkisiyle karşılaşmıştır. Mekke'de karşılaştığı tepkiler üzerine Bağdat'a tekrar geri dönen Hallâc, burada yaklaşık bir sene kalmış ve daha sonra ikinci kez Hindistan seferine çıkmıştır. Bu yolculuğunda başta Hindistan olmak üzere Horasan, Türkistan, Mâverâünnehir bölgelerini dolaşmış ve bu bölgelerdeki insanları Hakk'a çağırmıştır. ${ }^{24}$

íkinci Hindistan seferinden sonra Hallâc aleyhine tepki ve konuşmalar çoğalmaya başlamıştır. Hallâc'ın hayatı hakkında ikinci Hindistan seferi kıstas alınarak öncesi ve sonrası olmak üzere iki döneme işaret edilmektedir. Hallâc'ın birinci dönemi daha çok zühd ve ibadet ağılıklı kabul edilerek genel kabul görürken ikinci dönem ise dine muhalif görülen bazı sözlerinden dolayı eleştiri ve tenkide maruz kalmıştır. íkinci Hindistan seferinden sonra Hallâc 288/901 tarihinde üçüncü haccını ifa için Mekke'ye yönelmiş ve burada iki yıl daha kalmıştır. Mekke'den sonra290/903 yılında Bağdat'a dönen Hallâc, burada bir ev inşa ederek insanlara görüş ve düşüncelerini anlatmaya başlamıştır. ${ }^{25}$

\section{Sorgulama ve Mahkeme Süreçleri}

Kaynaklardan edinilen bilgiye göre Hallâc, 299/911, 301/913 ve nihai tarih 309/922 olmak üzere üç sorgu ve mahkeme süreci geçirmiştir.

22 Bağdâdî, Târîhu Bă̆dâd, 8/689; Sem'ânî, el-Ensâb, 4/316; Zehebî, Siyeru a'lâmi'lnübelâ, 11/194.

23 Bağdâdî, Târîhu Bă̆dâd, 8/689;

24 Bağdâdî, Târîhu Bă̆dâd, 8/690-691; İbnü'l-Cevzî, el-Muntazam, 13/202; Sem‘ânî, elEnsâb, 4/316; Zehebî, Siyeru a'lâmi'l-nübelâ, 11/194-196; Rıza Bakış, Âsı̆ğın Tevhîdi (İstanbul: İnsan Yayınları, 2013), 24.

25 Bağdâdî, Târîhu Bağdâd, 8/691; Zehebî, Siyeru a'lâmi'l-nübelâ, 11/195. 


\subsection{9/911 Tarihinde Yapılan Sorgulama}

Hallâc'ın ilk sorguya çekiliş tarihi 299/911'dir. Üçüncü haccından sonra Bağdat'a yerleşen Hallâc, burada dokuz yıl boyunca inşa ettiği tekke aracilığıyla insanlara görüş ve düşüncelerini anlatamaya başlamıştır. Hallâc'ın ittihat ve hulûlü çağrıştıran sözleri, Bağdat ulemâ ve meşâyıhının tepkisini çekmeye başlamıştır. Bu tepkiler üzerine Vezir Ebü'l-Hasan ibnü'l-Fırât 299/911 tarihinde ilk sorguyu başlatmış ve Hallâc'ı tutuklatmıştır. Hallâc'a üç gün direğe bağlı olarak teşhir edilme cezası verilmiştir. Bu teşhir cezasından sonra Hallâc'ın ne kadar süre tutuklu kaldığına dair elimizde net bir bilgi yoktur. ${ }^{26}$

Hallâc'a ilk cezayı veren Vezir Ebü'l-Hasan İbnü'l-Fırât'ın tam ismi, Ali b. Muhammed b. Musa b. el-Fırât'tır. İbnü'l-Fırât'ı 296/908 senesinde Abbasî halifesi Muktedir-Billâh (ö. 320/932) vezirliğe getirmiş ve üç yıl sekiz ay sonunda da vezirlikten azletmiştir. İlk vezirliğinin son zamanlarında Hallâc'ın sorgusunu tamamlayan ibnü'l-Fırât, daha sonraki süreçte Muktedir-Billâh tarafından ikinci kez vezirlik makamına getirilmiştir. İbnü'l-Fırat'ın bu ikinci vezirliği de bir yıl beş ay sürmüştür. ${ }^{27}$

\subsection{1/913 Tarihinde Yapılan Sorgulama}

Hallâc'ın ikinci sorgusu 301/913 yılında başlatılmıştır. Bu sorguyu ibnü'I-Fırât'tan sonra 300/912 yılında vezirlik makamına getirilen Ebü'lHasan Ali b. Îsâ el-Kunnâî (ö. 334/945) başlatmıştır. Sorguda Vezir Ali b. Îsâ ilk olarak Hallâc'a abdest, namaz, farzlar gibi dinî konularda sorular yöneltmiştir. Daha sonra hulûl ve ittihat suçlamalarının yanı sıra Hallâc'a Karâmita önderi ve davetçisi olma suçlaması da yöneltilmiştir. Bu suçlamalar sonucunda Hallâc, tutuklanmış, çarmı ha gerilerek üç gün halka teşhir edilmiş ve daha sonra da Sultan'ın gözetiminde olmak üzere hapis cezasına çaptırımıştır. Hallâc bu tarihten katledildiği tarih olan 309/922 yııına kadar dokuz yıl hapis hayatı yaşamıştır. ${ }^{28}$

26 İbnü'n-Nedîm, el-Fihrist, 237; Sâî̂, Ahbâru'l-Hallâc, 44; Sem‘ânî, el-Ensâb, 4/317; İbn Hallikân, Vefayâtü'l-ayyân, 2/142; Zehebî, Siyeru a'lâmi'l-nübelâ, 11/195-197; Massignon, İslâm'ın Mistik Şehidi, 1/67.

27 Safedî, el-Vâfí bi'l-vefeyât, 22/91.

28 Ebû Ca'fer Muhammed b. Cerîr et-Taberî, Târîhu'l-ümem ve'l-mülûk (Târîhu't-Taberî), (Beyrût: Dârü'l-kütübi'l-ilmiyye, 1407), 5/677; İbnü'n-Nedîm, el-Fihrist, 237; Sâî́, Ahbâru'l-Hallâc, 44; Ebü'l-Hasan Ali b. Ebî'l-Kerem el-Cezerî İbnü'l-Esîr, el-Kâmil fi'ttârîh, thk. Ömer Abdüsselâm Tedmirî (Beyrût: Dârü'l-kitâbi'l-'Arabî, 1417/1997), 6/624; İbn Teymiyye, Mecmû'u'l-fetâvâ, 35/109; Ebû Abdillâh Semseddin Muhammed b. Ahmed ez- Zehebî, Târîhu'l-İslâm ve vefayâtü'l-meşâhir ve'l-ęlâm, nşr. Ömer Abdüsselam Tedmirî ( Beyrut: Dârü'l-kitâbi'l-'Arabî, 1407/1987), 23/8; Zehebî, Siyeru a'lâmi'l-nübelâ, 11/202, 371;Ebû Bekir Abdurrahman es-Suyûtî, Târîhu’l-hulefâ, thk. 
Bu sorguda Hallâc'ın katline bir hükmün çıkmamasında Hamd elKunnâî́nin etkisinin olduğunu vurgulamak gerekir. Çünkü Kunnâî, Hallâc taraftarıdır. Vezârette görevli bir devlet adamı olan Kunnâî, aynı zamanda Vezir Ali b. Îsâ el-Kunnâî́nin de amcasının oğludur. Bu hususiyetlere sahip olan Hamd el-Kunnâî, soruşturmanın katl ile neticelenmemesi için gayretleri olmuş bu manada da kadılara baskılar yapmıştır. ${ }^{29}$

\subsection{9/922 Tarihli Nihaî Mahkeme}

\subsubsection{Mahkeme Öncesinde Genel Durum}

Hallâc'ın idamında Abbâsî Devleti'nin başında Muktedir-Billâh yer almaktadır. Küçük yaşta devlet yönetimi ve halifelik makamına getirilen Muktedir-Billâh idareye tam hâkim olamadığından devlet idaresi daha çok kadınlar ve devlet bürokrasisinde yer alan şahıslar kanalıyla yürütülmektedir. Bu durum da ülke coğrafyasında görülen huzursuzluk ve kargaşaları artırmaktadır. ${ }^{30}$

Hallâc'ın katlinden bir sene öncesinde 308/921 yılında Bağdat'ta büyük çapta huzursuzluk, kargaşa ve çatışmalar vukû bulmuştur. Kargaşa ve huzursuzluğun ana sebebi Vezir Hâmid'in halka karşı uyguladığı zülüm ve haksızlıklardır. Zulüm ve haksızlıklara isyan eden Bağdat halkı vezirin evini kuşatmış ve bunun neticesi olarak halk ile vezirin maiyetinde bulunan şahıslar arasında günlerce süren çatışmalar vuku bulmuştur. Bu çatışmalar neticesinde her iki taraftan çok sayıda insan ölmüştür. Bağdat'ta çatışmaların yanı sıra soygun ve yağma faaliyetleri de çoğalmıştır. ${ }^{31}$

Devlet idaresini rahatsız eden en önemli sorunların başında Karâmita isyanları gelmektedir. Karâmita isyanlarının önlenememesi devlet idaresini zaaf içine sokmuştur. Karmatîler Muktedir-Billâh zamanında isyanlarını artırmışlar ve bu bağlamda 309/922 yılında Mekke'ye saldırarak 'Hacerü'I-esved'i Kâbe duvarından söküp yanlarına alarak götürmüşlerdir. Karmatîler bu taşı yirmi yıldan daha fazla bir süre kendi yanlarında

Muhammed Muhyiddîn Abdulhamîd (Mısır: Matba'atü's-se‘̂ade, 1371/1952), 328; Bakış, Âşı̆ın Tevhîdi, 29.

29 İbnü'n-Nedîm, el-Fihrist, 237; Sâî̀, Ahbâru'l-Hallâc, 44; Zehebî, Târîhu'l-ìslâm, 23/8; Zehebî, Siyeru a 'âmi'l-nübelâ, 11/202, 371; Suyûtî, Târîhu'l-hulefâ, 328; Bakış, Âşı̆̆ın Tevhîdi, 29.

30 Muhammed b. Ali b. et-Tıktakâ, el-Fahrî fi'l-âdâbi'l-sultâniyye ve'd-düveli'l-İslâmiyye, thk. Abdülkâdir Muhammed Mâyû (Beyrût: Dârü'l-kalemi'l-'Arabî, 1418/1997), 255.

31 Ebû Abdillah Muhammed b. Ahmed ez-Zehebî, el-'Tber fî haberi men ğaber, thk. Ebû Hacer Muhammed es-Saîd (Beyrût: Dârü'l-kütübi'l-ilmiyye, 1985), 1/453. 
bulundurduktan sonra Hz. Ali'nin soyundan gelen Şerîf Yahyâ b. elHüseyin'e teslim etmişlerdir. ${ }^{32}$

Bu tarihlerde Vezir Hâmid, ülke coğrafyasında görülen huzursuzluk ve kargaşanın kaynağı olarak 301/913 tarihinden beri hapiste tutulan ve Karâmita'nın önderi ve davetçileri arasında kabul ettiği Hallâc'ı görmektedir. Hallâc yaklaşık dokuz yıldır hapiste olmasına rağmen Hâcib Nasır elKuşûrî'nin de yardımıyla görüş ve düşüncelerini rahat bir şekilde yaymaya ve birçok taraftar edinmeye devam etmiştir. Halk onun ölüleri dirilttiğine, cinlerin onun hizmetinde olduğuna, ne isterse cinlerin onun isteğini yerine getirdiğine inanmaktadır. Bazı insanlar onun bir nebî olduğuna bazıları daha ileri giderek onun bir ilah olduğunu itikat etmeye başlamışlardır. ${ }^{33}$

\subsubsection{Yargılama Safhası}

Vezir Hâmid, sorunun kaynağı olarak gördüğü, hapiste tutuklu olan Hallâc'ı yargılamak üzere kendisine teslim edilmesini Halife MuktedirBillâh'dan ister. Bu isteğe Muktedir-Billâh, Hallâc taraftarı olan Nasır elKuşûrî'nin de desteğini alarak ilk önce karşı çıkar. İlk kaynaklar arasında yer alan İbnü'n-Nedîm'e (ö.385/995) göre Muktedir-Billâh bırak vezirine teslim etmeyi Hallâc'ı serbest bırakma niyetindedir. Çünkü Hallâc, başta halife olmak üzere, halifenin elinin altındaki kadınlara ve hizmetkârlara hep dua etmektedir. Tutukluluk hayatında çok az yemekle kifayet eden Hallâc, sürekli namaz kılmakta ve sürekli oruç tutarak vaktini geçirmektedir. Kuşûrî, bu davranışlarından dolayı Hallâc'a 'Sâlih Şeyh' olarak hitap etmekte ve ona saygı göstermektedir. ${ }^{34}$

Bir diğer ilk kaynaklar arasında yer alan Ebû Ali et-Tenûhî (ö. 384/994) de eserinde Muktedir-Billâh'ın Hallâc'ı serbest bırakma düşüncesine tesir eden bazı olaylara yer vermektedir. Eserde kaydedilen bilgiye göre Muktedir-Billâh bir karın rahatsızlığına yakalanır. Bu duruma vâkıf olan Hâcib Nasır el-Kuşûrî, Muktedir-Billâh'dan tutuklu Hallâc'ın yanına gelmesine ve kendisini görmesine izin vermesini ister. İznin verilmesi üzerine Hallâc, Muktedir-Billâh'ın yanına gelir ve elini halifenin karnının ağrıyan yerine koyarak ve bazı âyetler okur. Bunun neticesinde Muktedir-

32 İbnü'l-Tiktakâ, el-Fahrî fi'l-âdâbi'l-sultâniyye, 255.

33 Ebû Ali Ahmed b. Muhammed b. Miskeveyh, Tecâribüll-ümem ve te âkıbü'l-himem, thk. Ebü'l-Kâsım İmâmî (Tahrân: Serûş, 2000), 5/132; İbnü'l-Cevzî, el-Muntazam, 13/143; İbnü'l-Esîr, el-Kâmil fi't-târîh, 6/671.

34 İbnü'n-Nedîm, el-Fihrist, 237. 
Billâh, karın ağrısından kurtulur. Benzer durum Muktedir-Billâh'ın annesi için de vukû bulmuş oda aynı şekilde Hallâc'ın duasıyla şifa bulmuştur. ${ }^{35}$

Vezir Hâmid, Muktedir-Billâh'dan Hallâc'ın kendisine teslim edilmesi ve yargılamanın yapılması hususunda ısrarcı olmuştur. Vezir ısrarını Muktedir-Billâh'a şu şekilde ifade etmiştir: 'Hallâc'ın eliyle insanlar dinden çıkıyor, mürted oluyor. Bu durum ileride senin saltanatının zevâline sebep olur. Beni bırak ben onu yargılayayım ve onu öldüreyim. Bundan dolayı sana bir menfi durum isabet ederse o zaman sen de beni öldürürsün. ${ }^{36}$ Bu ısrar ve gerekçe üzerine Muktedir-Billâh, Hallâc'ın vezire teslim edilmesine izin vermiş̧ir.

Hallâc'ı teslim alan Vezir Hâmid, kendisinin başkanlığında Bağdat'ın iki kadısı Ebû Ömer Muhammed b. Yûsuf (ö. 320/932) ve Ebû Ca'fer Ahmed b. İshâk b. el-Bühlûl'ün (ö. 318/930) de yer aldığı bir mahkeme heyeti teşkil eder. Bu heyetin içinde sayısını tam olarak bilemediğimiz fukahâdan bazı isimler de yer alır. Mahkemenin ilk safhasında Vezir Hamid, sadece Hallâc hakkında iddiaları gündeme getirerek, Hallâc'a savunma hakkı vermeden, delilleri ortaya koymadan şahitleri dinlemeden bir an önce karar çıkartma arzusunda olmuştur. Çünkü onun zihninde Hallâc'ın hükmü sabit olmuş ve bir an önce karar çıkarılarak infazının uygulanması gerekmektedir. Ancak mahkeme heyeti, sanığın ikrarı ve açık deliller olmadan sadece iddia üzerine karar vermenin caiz olmayacağı gerekçesiyle vezirin bu isteğini geri çevirmiştir. ${ }^{37}$

İsteği kabul edilmeyen Vezir Hâmid, Hallâc'ın katline delil teşkil edecek suç unsurları arayışlarını girişmiştir. ${ }^{38}$ Bu manada Hallâc, mahkeme heyeti önüne çıkarılmış günlerce konuşturularak onun konuşmalarından şeri'ata muhalif suç unsuru aranmıştır. Ancak mahkeme heyeti onun konuşmalarından idamına gerekçe olacak bir suç unsuru tespit edememiştir. Bu konuda umduğunu bulamayan vezir, şahitler kanalıyla suç unsuru tespitine yönelmiştir. Bu manada da vezir, Hallâc'ın dostlarından es-Simmarî, Haydar ve Muhammed b. Ali el-Kannâ gibi bazı isimleri mahkeme önüne getirerek onların konuşma ve şahitliklerinden Hallâc aleyhine suç tespitine çalışmışır. Ancak burada da mahkeme heyetini tam manasıyla tatmin edecek bir suç unsuru oluşmamıştır. ${ }^{39}$

35 Tenûhî, Nişvârü'l-muhâdara, 6/80; Zehebî, Siyeru a'lâmi'l-nübelâ, 11/208.

36 Tenûhî, Nişvârü'l-muhâdara, 1/164.

37 İbnü'l-Esîr, el-Kâmil fi't-târîh, 6/672.

38 Bağdâdî, Târîhu Bağdâd, 8/707; Sem'ânî, el-Ensâb, 4/317; İbn Miskeveyh, Tecâribü’lümem, 5/132; İbnü’l-Verdî, Târîhu İbnü'l-Verdî, 1/247; Bakış, Âşı̆̆ın Tevhîdi, 31.

39 İbn Miskeveyh, Tecâribü'l-ümem, 5/135; Zehebî, Siyeru a'lâmi'l-nübelâ, 11/198 
Hallâc'ın konuşmalarından ve tanıkların ifadelerinden tatmin edici bir suç unsurunu mahkeme heyetinin önüne koyamayan Vezir Hâmid, bu sefer Hallâc'a âit olduğu iddia edilen bazı kitapları mahkemenin gündemine getirmiştir. Bu manada mahkeme heyetinin önüne ismi ' من الرحمن 'Mine'r-Rahmâni'r-Rahîm ilâ fulâni'b-ni fülân' olan yani 'Rahmân ve Rahîm'den falan oğlu falana' anlamına gelen bir kitabı getirmiştir. Kitap Hallâc'a gösterildiğinde Hallâc: "Bu benim hattım ve bu benim yazım" diyerek kitabın kendisine ait olduğunu kabul etmiştir. ${ }^{40}$

Bunun üzerine mahkeme heyeti Hallâc'a: "Sen nübüvvet iddiasında bulunuyordun, bu iddia rubûbiyyete mi yöneldi? diye suçlama yöneltmiştir." Bu suçlamayı kabul etmeyen Hallâc kendisinin Allah'a ibadet eden, çok namaz kılan ve çok oruç tutan bir kul olduğunu hatırlatarak bu durumun rubûbiyyet iddiası değil, عين الجمع 'aynü'l-cem" hâli olduğunu ifade etmiştir. Hallâc'a göre bu hâlde gerçek fâil Allah'tır, kendisi ve eli alet konumundadır. ${ }^{41}$ Mahkeme heyeti Hallâc'a: "aynü'l-cem' hâlini kendisi dışında bilen başka bir kimselerin var olup olmadığını sorduğunda." Bu soru üzerine Hallâc kendisini destekleyebilecek üç şahsın ismini zikretmiştir. Bu şahıslar; Ebü'l-'Abbâs b. 'Atâ (ö. 309/922), Ebû Muhammed el-Cerirî (ö. 321/933), ve Ebû Bekir eş-Şiblî́dir(ö. 334/946). ${ }^{42}$

Ünlü sûfî müellif Ebû Abdurrahmân es-Sülemî (ö. 412/1021) eserinde aynü'l-cem'ı tefrikadan kesilme yani mâsivâdan uzaklaşarak Hak ile beraber olma hâli olarak tarif etmektedir. ${ }^{43}$ Abdülkerîm el-Kuşeyrî (ö. 465/1072) de Letâifü'l-işârât adlı eserinde '...Attığın zaman sen atmadın, fakat Allah attı...' anlamına gelen (Enfâl, 8/17.) âyetini ${ }^{44}$ delil getirerek âyette ifade edilen $\mathrm{Hz}$. Peygamber (a.s.) hâlinin, aynü'l-cem' olduğunu belirtmiştir. ${ }^{45}$

Bazı eserlerde Hallâc'ın öldürülmesine bir gerekçe olarak Abbasîlere karşı ayaklanmış Karmatîlerle olan ilişkisi ifade edilirken diğer bir gerekçe de 'Ene'l-Hak' sözünü söylemesi ve bu sözüyle ulûhiyyet iddiasında bu-

40 Bağdâdî, Târîhu Bağdâd, 8/706; İbnü'l-Cevzî, Telbîsü İblîs, 154; 'Askalânî, Lisânü'lmîzân, 3/211.

41 Bağdâdî, Târîhu Bağdâd, 8/706; İbnü'l-Cevzî, Telbîsü İblîs, 154; 'Askalânî, Lisânü'lmîzân, 3/212; İbn Miskeveyh, Tecâribül-ümem, 5/132.

42 Bağdâdî, Târîhu Bağdâd, 8/706; İbnü'l-Cevzî, Telbîsü İblîs, 154; İbnü'l-Esîr, el-Kâmil fi't-târîh, 6/672; 'Askalânî, Lisânü'l-mîzân, 3/212.

43 Ebû Abdurrahmân Muhammed b. el-Hüseyin es-Sülemî, Hakâiku't-tefsîr (Tefsîru'sSülemî), thk. Seyyid 'Imrân (Beyrût: Dârü'l-kütübi'l-ilmiyye, 1421/2001), 2/125, 316.

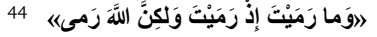

45 Abdülkerîm b. Hevâzin el-Kuşeyrî, Letâifü'l-işârât (Tefsîru'l-Kuşeyrî), thk. İbrâhim elBisyûnî 3 cilt. (Mısır: el-Heyetü'l-Mısriyyeti'l-âmme li'l-kütüb, 2000), 2/65. 
lunması gösterilir. ${ }^{46}$ Oysaki bu sözün mahkeme safhasında hiçbir şekilde gündeme gelmediğinin bilinmesi gerekir. İlk kaynak olan Ebû Ca'fer etTaberî (ö. 310/923) bu hususu eserinde hiç gündeme getirmediği gibi ${ }^{47}$ Hallâc konusunda en detay bilgilere yer veren Hatîb el-Bağdâdî (ö. 463/1071) de hacimli eseri Târîhu Bağdâd' da bu hususu hiç zikretmemiştir. Hatîb el-Bağdâdî’nin eserinde biyografisine en geniş yer verdiği şahıslardan birisi Hallâc'tır. Hallâc konusunda lehte ve aleyhte otuz iki sayfayı bulan bilgileri kitabına kaydeden Hatîb el-Bağdâdî yargılamada esnasında Ene'I-hak sözünün gündeme geldiğine dair bir bilgiye yer vermemiştir. ${ }^{48}$

Esasında Hallâc'ın 'Ene'l-Hak' sözünü söyleyip söylemediği tartışmalı bir konudur. Hallâc'ın eserlerini tetkik eden ve Divan'ını oluşturan Fransız şarkiyatçısı Louis Massignon (ö.1962/1382) bu sözün Hallâc'ın eserlerinde geçmediğini, ancak öğretisine uygun olarak onun tarafından söylenmesinin de mümkün olduğunu ifade etmektedir. ${ }^{49}$ Abdülkâhir elBağdâdî'nin (ö. 429/1037) el-Fark beyne'l-fırak adlı eserine bakıldığında Hallâc'ın bu ifadeyi kullandığı görülmektedir. Eserdeki kayda göre Hallâc bir gün Cüneyd-i Bağdâdî̀ye uğrar ve ona: أَنَّا الحَقَّ “Ene'l-Hak"der. Cüneyd bu sözü doğru bulmaz ve Hallâc'a şöyle der: أَنْتَ "Ente bill'-Hak." Daha sonra Cüneyd, Hallâc'a duyduğu öfkeyi ve rahatsızlığı şu şekilde ifade eder: "Bakalım hangi darağacında kanın akacak?"50

Hallâc'tan Ene'l-Hak sözünün sudûrunu mümkün görenlerden birisi İmam Gazzâlî’dir (ö. 505/1111). Gazzâlî, Mişkâtü'l-envâr adlı eserinde âriflerin mecaz çukurundan kurtulup hakikat semâsına urûç ettiklerinde el-Vâhidü'l-Hak'tan başka bir varlık görmediklerini beyan etmektedir. Gazzâlî'ye göre bu durumda tamamen kesret kalkmış ve sırf tekliğe, vahdete ğark olunmuştur. Bu hâlde ârifin aklı giderek bayılma gibi durum olmuş ve Allah'tan başka hiçbir şeyi hatırlamağa gücü kalmamıştır. Bu hâl aklın otoritesinin kaybolduğu, manevî sarhoşluk hâlidir. Bu durumda bazıları 'Ene'l-Hak'... gibi bazı şathiyelerde bulunmuşlardır. ${ }^{51}$

46 Ebü'l-Fadl el-Kâdî 'Iyâd b. Mûsâ, eş-Şifâ bi ta'rîfi hukûkı'l-Mustafâ, thk. Ahmed b. Muhammed eş-Şemnî (Lübnân: Dârü'l-fikir, 1409/1988), 2/297-298; İbn Hallikân, Vefayâtü'l-a'yân, 2/140; Uludağ, "Hallâc-1 Mansûr", 15/378.

47 Taberî, Târîhu'l-ümem ve'l-mülûk, 5/677;

48 Bağdâdî, Târîhu Bağdâd, 8/688-720

49 Massignon, İslâmın Mistik Şehidi, 1/179.

50 Bağdâdî, el-Fark beyne'l-firak, 247; Zehebî, Siyeru a'lâmi'l-nübelâ, 11/204

51 Ebû Hâmid el-Gazzâlî, Mişkâtü'l-envâr, nşr. Ebu'l-'Alâ 'Afîfî (Kahire: el-Mektebetü'l'Arabiyye, 1383/1964), 57. 
Ferîdüddîn Attâr'a (ö. 618/1221) göre ise nasıl ki bir ağaçtan "Innenî ene'I-Ilah"52 ifadesi zuhûr etmişse Hak âşığı Hallâc'tan da Ene'I-Hak sözü öyle zuhûr etmiştir. Bir ağaçtan bu ifadenin sudûrunu caiz görenlerin aynı şekilde bunu Hallâc için mümkün görmemelerine şaştığını ifade eden Attar, bu konuda “Hakk'ın, Hz. Ömer'in (ö. 23/644) diliyle konuştuğu rivayetini ${ }^{53}$ delil getirmektedir. Attar'a göre Hak nasıl ki Hz. Ömer'in diliyle konuşmuşsa Hallâc'ın diliyle de aynen o şekilde konuşmuştur. Ancak burada ne hulûl, ne de ittihat vardır. ${ }^{54}$

Hallâc'ın katli için gayretlerini artıran Vezir Hâmid, Hallâc'ın diğer bir kitabını mahkeme heyetinin önüne koyar. Bu kitapta şu ifadeler kayıtlıdır: 'Bir insan hac yapmayı murâd eder, ancak bu mümkün olmazsa, evinde necasetin bulaşmadığı ve kimsenin de izinsiz giremediği bir odayı kendisine Kâbe edinir. Hac günleri geldiğinde bu odanın etrafını tavaf eder. Mekke'de hacıların yaptığı tüm menâsiki de yapar. Sonra otuz yetimi toplar, onlara yemek hazırlar ve onları doyurur. Yemek işi tamamlandıktan sonra da onları giydirir. Ayrıca onların her birine dokuz veya üç dirhem para verir. Böyle yapan bir insan hac yapmış gibi olur. ${ }^{55}$

Kadı Ebû Ömer Muhammed b. Yûsuf: "Okunan bu bilgileri nereden aldığını? Hallâc'a sorar." Hallâc da: "Hasan-ı Basrî́nin ihlâs kitabından aldığını söyler." Kadı Ebû Ömer hiddetlenerek: " يا حلال الام Ey kanı helâl olan! Yalan söylüyorsun diyerek çıkışır." Ihlâs kitabını kendisinin de okuduğunu söyleyen Kadı Ebû Ömer, bu kitapta böyle bir şeyin olmadığını ifade eder. Vezir Hâmid, 'Ey kanı helâl olan!' sözünü işitince Kadı Ebû Ömer'den bu ifadeyi tutanağa yazarak hüküm ve kararı vermesini ister. Kadı Ebû Ömer ilk önce mahkeme tutanağına bu ifadeyi yazmak istemez. Ancak vezirin baskısı üzerine bu ifadeyi yazar. Mahkeme heyetinde bulunan ve ayrıca daha sonra meclise katılan şahıslar karara katılarak tutanağı imzalarlar. ${ }^{56}$

Hallâc karara karşı ı̧ıkar ve kendisini şu şekilde savunur: "Benim kanım size helal değildir. Benim itikadım İslâm'dır. Benim mezhebim sünnettir." Hallâc ayrıca hulefâ-i râşidîni ve aşere-i mübeşşereyi tafdîl ettiği-

2 من الثجرة أن يا موسى إني أنا الله رب العالمين"bk. (Kasas, 28/30.)

3 Benzer rivayetler için bk. Tirmizî, “Menâkıb”, 17, hadis no: 3682.

4 Attâr, Tezkiretü'l-Evliyâ, 705.

55 Tenûhî, Nişvârü'l-muhâdara, 6/87; Bağdâdî, Târîhu Bă̆dâd, 8/718; İbn Miskeveyh, Tecâribü'l-ümem, 5/137; İbn Hallikân, Vefayâtü'l-ayân, 2/143; İbn Teymiyye, Mecmû́u'l-fetâvâ, 35/109.

56 Tenûhî, Nişvârü'l-muhâdara, 6/87; Bağdâdî, Târîhu Bağdâd, 8/718; Zehebî, Siyeru a'lâmi'l-nübelâ, 11/210; Yâfi'î, Mirâtü'l-cenân, 2/194. 
ni de ifade eder. ${ }^{57}$ Hallâc'a hac konusunda olduğu gibi ayrıca namaz, oruç ve zekât gibi konularda da dinin rükunlarını tahrif ve tebdil suçlamaları yöneltilmiştir. ${ }^{58}$

İstediğini elde eden Vezir Hâmid, mahkeme kararını ve ulemâ fetvalarını onay makamı olarak Halife Muktedir-Billâh'a arz etmiş ve ondan cezanın infazı için izin istemiştir. Muktedir-Billâh, iki gün gecikmeli olarak kadıların hükmüne istinaden infaza izin vermiştir. İzin yazısında Muktedir-Billâh, Hallâc'ın cellat Muhammed b. Abdüssamed'e teslim edilmesini, infaza ilk önce bin kırbaç vurularak başlanılmasını eğer ölmezse boynunun koparılmasını emretmiştir. Ancak Vezir Hâmid, bu yazıdaki infaz icra hususlarını yetersiz görerek buna el ve ayakların kesilmesi, cesedin yakılması, başın köprü üzerine dikilerek teşhir edilmesini de ilave etmiştir. $^{59}$

Hüküm büyük bir halk topluluğunun önünde 23 Zilkâde 309/25 Mart 922 tarihinde Bağdat'ın Bâbü't-Tâk denilen yerinde infaz edilmiştir. Hallâc'a ilk önce bin kırbaç vurulmuş, kol ve ayakları teker teker kesilmiş ve sonra da idam edilerek başı koparılmıştır. Kesilen başı Dicle üzerindeki köprüye dikilmiş ve gövdesi yakılıp külleri de nehrin sularına atılmıştır. Kesik başı iki gün köprüde dikili kaldıktan sonra Horasan'a gönderilerek bölgede dolaştırılmıştır. ${ }^{60}$

\section{Hallâc'ın Katline Fetvâ Veren ve Karara İmza Atanlar}

Hemen hemen tüm kaynaklarda ulemânın ittifak ve icmâsıyla, küfür ve zındıklık gerekçe gösterilerek Hallâc'ın katline karar verildiği belirtilmektedir. Nihaî yargılamada Kadı Ebû Ömer'in Hallâc'ın kanının helal olduğuna hükmetmesinden sonra mecliste hâzır bulunan veya o anda bulunmayıp daha sonra meclise dâhil olan ulemâ, ittifak ile bu hükme katılmış ve karara imza atmışlardır. ${ }^{61}$ Kaynaklarda geçen bu genel ifade-

57 Tenûhî, Nişvârül-muhâdara, 6/88; İbn Miskeveyh, Tecâribü'l-ümem, 5/138; İbnü'lEsîr, el-Kâmil fi't-târîh, 6/673; 'Âmilî, el-Keşkûl, 1/196; Yâfiî̀, Mirâtül-cenân, $2 / 194$.

58 İbnü'l-Cevzî, el-Muntazam, 13/205.

59 Tenûhî, Nişvârü'l-muhâdara, 6/89; Sem‘ânî, el-Ensâb, 4/317; Zehebî, Siyeru alâmi’nübelâ, 11/210; İbnü'l-Verdî, Târîhu İbnü'l-Verdî, 1/248; 'Âmilî, el-Keşkûl, 1/196.

60 Taberî, Târîhu'l-ümem ve'l-mülûk, 5/677; Sülemî, Tabakâtü’s-sûfiyye, 308; Bağdâdî, Târîhu Bağdâd, 8/706, 720; Tenûhî, Nişvârüll-muhâdara, 6/91; İbn Miskeveyh, Tecâribü'l-ümem, 5/139; Sem'ânî, el-Ensâb, 4/318; İbnü'l-Esîr, el-Kâmil fi't-târîh, 6/673; 'Âmilî, el-Keşkûl, 1/196.

61 Bağdâdî, el-Fark beyne'l-firak, 247-249; İbnü'l-Cevzî, el-Muntazam, 13/205; İbnü'lCevzî, Telbîsü İblîs, 154; İbnü'l-Esîr, el-Lübâb, 1/403; İbn Teymiyye, el-Fetâvâ elKübrâ, 3/481; İbn Teymiyye, Mecmû'u'l-fetâvâ, 2/480; İbnü'l-Verdî, Târîhu İbnü'l- 
lerden Hallâc'ın katline fetvâ veren ve karara imza atan ulemânın kimler olduğunu ayrıntılı olarak isim düzeyinde bilmek mümkün değildir. Hallâc konusunda en geniş ve en ayrıntılı bilgiyi veren Hatîb el-Bağdâdî bile tek tek ulemânın isimlerini zikretmemiş, genel bir ifade olarak ulemâ arasında ittifak ve icmanın var olduğunu belirtmekle yetinmiştir. ${ }^{62}$

Hallâc'ın katli konusunda fetvâ veren ve karara imza atan ulemânın isim ve sayı düzeyinde net olarak bilinmemesi icmanın varlığını şüpheye düşürse de bazı isimler icmânın varlı̆̆ı konusunda şüphe duymamaktadır. Bu isimlerden birisi Kadı 'Iyâd'dır (ö. 544/1149). Kadı 'Iyâd, eş-Şifâ adlı eserinde Hallâc'ın; 'Ene'l-Hak' ve hulûle dâir sözlerinden ve rubûbiyyet iddiasından dolayı ulemânın icmâsıyla asıldığını ve öldürüldüğünü ifade etmiştir. Kadı 'Iyâd, cezâ infaz edilmeden önce Hallâc neden tövbeye davet edilmedi? Tövbeye davet edilmesi gerekmez miydi? eleştirilerine; kâfir olan bir kimsenin tövbeye davet edilip edilmemesi konusunda iki farklı görüşün olduğunu hatırlatarak mahkemenin bu konuda tövbeye davet etmeme görüşünü tercih ettiğini ifade ederek cevap vermiş̧ir. Kadı 'Iyâd'a göre bu karar daha sonra Halife Râzî-Billâh (ö.329/940) zamanında vuku bulan İbn Ebî'l-'Azâfir olayına örnek teşkil etmiş ve hüküm ibn Ebî'l-'Azâfir'e de aynen uygulanmıştır. ${ }^{63}$

Bazı eserlerde İbn Ebî'l-'Azâfir olarak meşhur olan Muhammed b. Ali b. es-Selemkânî'nin hulûl iddiasında bulunduğu ve kendisini 'Rûhu'I-Kuds olarak isimlendirdiği beyan edilmektedir. Taraftarlarına el-Hâsse essâdise isminde bir kitap yazan ỉbn Ebî'l-'Azâfir bu kitapta şeri'atın kalktığını ve livâtayı mübah gördüğünü ifade etmiştir. Bu görüşlerinden dolayı İbn Ebî'l-'Azâfir 322/933 yılında Hallâc'a verilen kararın aynısına tabi tutularak cezası infaz edilmiştir. ${ }^{64}$

Kadı 'Iyâd dışında mahkeme kararını doğru bulan ve konu hakkında ulemânın ittifak ve icmâsının var olduğunu güçlü bir şekilde savunan bir diğer şahıs Ebü'l-Ferec i̇bnü'l-Cevzî'dir (ö. 597/1201). İbnü'l-Cevzî icmâ konusunda en ufak bir şüphe duymamakta ve icmâyı desteklemektedir. "...Ümmetin dalâlet üzerine birleşmeyeceğini..." ifade eden hadisi ${ }^{65}$ delil

Verdî, 1/248; Safedî, el-Vâfî bi'l-vefeyât, 13/47; 'Askalânî, Lisânü'l-mîzân, 3/211; Yâfiî̀, Mirâtü'l-cenân, 2/193;

62 Bağdâdî, Târîhu Bağdâd, 8/688-720.

63 Kâdî 'Iyâd, eş-Şifâ, 2/297-298.

64 Bağdâdî, el-Fark beyne'l-firak, 250.

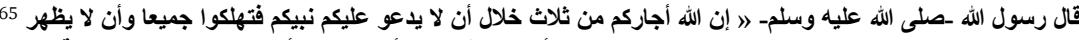
هk. Ebû Dâvud, "el-Fiten ve'l-melâhim”, 1, hadis no: 4253. 
getiren İbnü'l-Cevzî, ulemânın fetva ve kararını da hatadan uzak ve masum kabul etmiş̧ir. ${ }^{66}$

İbn Teymiyye (ö. 728/1328) de Kadı 'lyâd ve İbnü'l-Cevzî'nin izinden giderek Hallâc'ı küfür ve zındıklıkla itham etmiş ve konu hakkında ulemânın ittifak ve icmasının var olduğunu güçlü bir şekilde beyan etmiştir. İbn Teymiyye görüşünde o kadar katıdır ki, 'Hallâc haksız yere öldürüldü' diyenlere bile tahammül edememekte ve onlara ağır suçlamalar yöneltmektedir. İbn Teymiyye'ye göre böyle söyleyenler ya mülhid ya münafık ya dâl ya da câhildir. Ayrıca İbn Teymiyye Hallâc'ın ölmeden önce tövbe edip etmediği hususuna da değinerek bu konuda kendisinin bir bilgisinin olmadığını ancak öldürülmeden önce bâtınî olarak tövbe etmişse bu tövbenin kendisine fayda vereceğini belirtmiştir. Ona göre her ne kadar Hallâc'ın bâtınî yönü bilinmese de fiil ve kavil yönünden küfür ve katlini gerektiren hususlar zâhir olmuştur. ${ }^{67}$

Nakşibendiyye tarikatının müessisi Bahâeddin Nakşibend'in (ö. 791/1389) önde gelen talebelerinden Hâce Muhammed Parsâ (ö. 822/1420) ise bu değerlendirmelere hiçbir şekilde katılmamakta Hallâc'ın küfür ve zındıklıkla ithamlarına şiddetle karşı çıkmaktadır. Parsâ'ya göre müteahhirîn meşâyıh, Hallâc'ın şehit olduğuna ittifak etmişlerdir. Müteahhirînin bu konudaki ittifakı mütekaddimînin daha önceki ihtilafını ortadan kaldırmaktadır. Hallâc'ın asılsız iftira ve suçlamalarla katledildiğini ifade eden Parsâ, manevî bir sarhoşlukla kendini kaybeden bir insana hukuki bir müeyyidenin gerekmeyeceğini savunmuştur. ${ }^{68}$

\subsection{Hallâc'ın Katil Kararına Karşı Çıkanlar}

Her ne kadar kaynaklarda genel bir ifade olarak ittifak ve icmadan bahsedilse de bazı âlimler bu ittifaka dâhil olmamışlardır. Bu manada da Hallâc'ın katline fetvâ vermemiş ve karara da imza atmamışlardır. Bu âlimler şunlardır:

Ebû Ca'fer Ahmed b. İshâk b. el-Bühlûl (ö. 318/930):

Vezir Hâmid'in tüm baskılarına rağmen, Hallâc'ın küfür ve zındıklığına fetva vermeyen ve kararı da imzalamayanlardan birisi Ebû Ca'fer Ahmed b. İshâk b. el-Bühlûl'dür. ${ }^{69}$ Bühlûl, diğer ulemâ ve kadıların aksine

66 İbnü'l-Cevzî, Telbîsü İblîs, 154.

67 İbn Teymiyye, el-Fetâvâ el-Kübrâ, 3/480-487.

68 Hâce Muhammed Parsâ, Tevhîde Giriş, trc. Ali Hüsrevoğlu (İstanbul: Erkam Yayınları, 2018),91-93.

69 Bağdâdî, Târîhu Bağdâd, 5/51, 13/90; İbnü'l-Cevzî, el-Muntazam, 13/292; İbn Kesîr, el-Bidâye ve'n-nihâye, 15/50. 
Hallâc'ın tövbeye davet edilmesi gerektiğini ifade etmiş ve tövbe ettiğinde de kendisine bir şeyin gerekmeyeceğini savunmuştur. ${ }^{70}$

Hanefî fakihi Bühlûl, 296-316/908-928 yıllar arasında yirmi yıl Bağdat kadısı olarak görev yapmıştır. Abbâsî halifesi Muktedir-Billâh tarafından 316/928 yılında görevden alınan Bühlûl 318/930 yılında Bağdat'ta vefat etmiştir. ${ }^{71}$ Hukuk dışında hadis alanıyla da temeyyüz eden Bühlûl, âdil ve sika kabul edilmiştir. Bühlûl aynı zamanda ünlü hadis âlimi Dârekutnî'nin (ö. 385/995) şeyhidir. Dârekutnî, Bühlûl'den birçok hadis almış ve o rivayetleri eserine kaydetmiştir. ${ }^{72}$ Bühlûl, Hallâc'ı yargılayan Bağdat'ın iki kadısından birisi olması hasebiyle önem arz etmektedir. Onun Hallâc aleyhine fetva vermekten ve karara imza atmaktan kaçınması dikkat çekici ve önemlidir. Çünkü Bühlûl, Hallâc'ı yargılayan iki kadıdan birisidir.

Ebü'l-'Abbâs Ahmed b. Muhammed b. 'Atâ (ö. 309/922)

Vezir Hâmid'in tüm baskılarına karşın Hallâc konusunda vezirin istediği fetvayı vermeyen isimlerden birisi de Ebü'l-'Abbâs Ahmed b. Muhammed b. 'Atâ'dır. Vezîr Hâmid, íbn 'Atâ'ya: “Hallâc konusunda ne dersin? diye sorduğunda İbn 'Atâ: "Bu konu sana ne gerek? Sen ilk önce aldığın malların ve döktüğün kanların hesabını ver" diyerek karşılık vermiştir. Bu söz üzerine Vezir Hâmid, ỉbn 'Atâ'nın dişlerinin sökülmesini emretmiştir. İbn 'Atâ çı̆̆lık atarak: "Allah senin de el ve ayaklarını kessin" diyerek beddua etmiştir. Bu olaydan on dört gün sonra ỉbn 'Atâ ölmüştür. ${ }^{73}$ Cüneyd-i Bağdâdî'nin en gözde talebelerinden olan İbn 'Atâ zühd ve ibadet ağırlıklı bir hayat geçirmiştir. İbn 'Atâ, Hallâc'ın itikadının sahih olduğunu kendi itikadının da aynen Hallâc'ın itikadı gibi olduğunu ifade etmiştir. $^{74}$

Ebü'l-Abbâs Ahmed b. Ömer b. Süreyc el-Bağdâdî (ö. 306/918)

Hallâc'ın katline fetva vermeyen bir diğer şahıs ünlü âlim Ebü'lAbbâs Ahmed b. Ömer b. Süreyc'tir. İbn Süreyc kendisinden fetvâ talep edildiğinde: "Bu adamın hali bana gizlidir. Ben onun ne dediğini anlamı-

70 Tenûhî, Nişvârü'l-muhâdara, 1/110, 163.

71 Bağdâdî, Târîhu Bağdâd, 5/51, 13/90; İbnü'l-Cevzî, el-Muntazam, 13/292 İbn Kesîr, el-Bidâye ve'n-nihâye, 15/50.

72 Ebü'l-Hasan Ali b. Ömer ed-Dârekutnî, Sünenü'd-Dârekutnî, thk. Şuayb el-Arnavûd, Hasan Abdülmün'ım Şiblî (Beyrût: Müessesetü’r-risâle, 1424/2004), 1/142, 2/158, 194, 432, 443, 481, 3/330, 366, 4/493, 5/452, 457, 512.

73 Zehebî, Siyeru a'lâmi'l-nübelâ, 11/157, 203; Attâr, Tezkiretü'l-Evliyâ,599- 608.

74 Parsâ, Tevhîde Giriş, 83. 
yorum. Anlamadığım konuda da fetva veremem" diyerek isteği geri çevirmiştir. 249/863 yılı doğumlu olan İbn Süreyc Şâfi'î ulemâsının büyüklerinden kabul edilmektedir. İbn Süreyc bir müddet Şiraz'da kadı olarak görev yapmıştır. ${ }^{75}$

İbn Süreyc Hallâc'ın katline fetva vermediği gibi bu konuda fetva veren ulemâyı da eleştirmiştir. Vefayâtü'l-a'yân adlı eserindeki kayda göre İbn Süreyc'e: "Hallâc'ın öldürülmesi konusunda fetva verenler hakkında ne dersin?" diye sorulduğunda ỉbn Süreyc bu soruya şu ayeti hatırlatarak cevap vermiştir: ${ }^{76}$ '...Siz, Rabbim Allah diyen bir adamı mı? öldürüyorsunuz...' (Mü'min, 40/28) 77

Vefayâtü'l-a'yân'da kaydedilen bu bilginin, İbn Süreyc'in 306/918 olan vefat tarihi dikkate alındığında problemli ve tevile muhtaç olduğu ortaya çıkmaktadır. Hallâc'ın öldürülmesinden üç sene önce vefat eden İbn Süreyc'in mahkeme heyetinin kararı hakkında bir şey söylemesi mümkün müdür? Bu soru önemlidir. Ancak bu soruya cevap olarak iki yaklaşım gösterilebilir. Birinci yaklaşıma göre bu tür nakiller, tarihi hakikate uymadığı gerekçesiyle reddedilir. İkinci yaklaşıma göre İbn Süreyc'in bu sözleri nihaî mahkeme öncesindeki diğer mahkeme süreçlerinde Hallâc'ın katline fetvâ veren ulema için söylediği gerçeğidir.

Sonuç olarak şunu ifade edebiliriz: Bühlûl, ỉbn 'Atâ ve ỉbn Süreyc gibi bazı isimler ulemanın ittifakına dâhil olmamışlar, Hallâc'ın katline açıkça karşı çıkmışlardır.

\subsection{Hallâc'ın Katline Fetvâ Verenler}

Hallâc'ın katli ve küfrü konusunda fetva veren şahıslar:

Vezir Hâmid b. el-'Abbâs (ö. 311/923):

Hallâc'ın öldürülme kararının alınmasında en etkili şahıs Vezir Hâmid b. el-'Abbâs'dır. Vezir Hâmid, ulemâyı zorlayarak kararının verilmesinde aktif rol almıştır. Hâmid b. el-'Abbâs 306/919 yılında Muktedir-Billâh tarafından vezir olarak atanmıştır. ${ }^{78}$ Kadı Ebû Ali et-Tenûhî (ö. 384/994) eserinde Vezir Hâmid'i gönlü geniş, mürüvvet sahibi, insanların yardımına koşan, onlara çok nimet bahşeden cömert bir insan olarak tavsif et-

\footnotetext{
75 Bağdâdî, el-Fark beyne'l-firak, 247; İbnü'n-Nedîm, el-Fihrist, 263; İbnü’l-Verdî, Târîhu İbnü'l-Verdî, 1/248; İbn Kesîr, el-Bidâye ve'n-nihâye, 14/831; Safedî, el-Vâfî bi'lvefeyât, 13/47; Câmî, Nefahâtü'l-üns, 290.

76 İbn Hallikân, Vefayâtü'l-ayân, 2/144.

" أتقتلون رجلا أن يقول ربي الله "

78 Tenûhî, Nişvârü'l-muhâdara, 1/22.
} 
miştir. Eserde Vezir Hâmid'in cömertliğine vurgu yapılarak her gün evinde kırka yakın sofranın kurulduğu, her gelenin yemek yediği ifade edilmiştir. ${ }^{79}$ Vezir Hâmid, varlıklı ve zengin bir şahıstır. Vezirliği öncesinde Vâsıt şehrinin idari işlerinin yürütülmesinde de görev almıştır. Silahlı dört yüze yakın korumaya sahip olan Vezir Hâmid, 309/922 yılında MuktedirBillâh'a yüz bin dinar harcadığı bir bahçeyi hediye etmiştir. ${ }^{80}$

Kadı et-Tenûhî'nin aksine diğer bazı kaynaklar ise ülkedeki kargaşa ve huzursuzluğun sebebi olarak bizzat Vezir Hâmid'i göstermektedir. Zulüm ve baskılar halkta vezire karşı bir hoşnutsuzluk yaratmıştır. Vezir Hâmid, zulüm ve baskılarını özellikle Hallâc taraftarlarına karşı artırmıştır. Bu manada vezirin zulüm ve işkence yaparak öldürdüğü şahıslardan birisi ibn 'Atâ'dır. ${ }^{81}$ ibn 'Atâ'nın bedduasını alan Vezir Hâmid 311/923 yılında elleri ve ayakları kesilerek öldürülmüştür. ${ }^{82}$ Abdurrahman Câmî (ö. 898/1492) eserinde vezirin dişlerinin tek tek sökülerek öldürüldüğü bilgisine yer vermiştir. ${ }^{83}$

Ebû Ömer Muhammed b. Yûsuf (ö. 320/932):

Son mahkeme sürecinde Hallâc'ın kanının helal olduğunu ilk söyleyen şahıs Mâlikî kadısı Ebû Ömer Muhammed b. Yûsuf'dur. Bağdat kadısı Ebû İshâk İsmâil b. İshâk'ın 282/896 yılında vefatından sonra onun yerine Ebû Ömer göreve getirilmiştir. ${ }^{84}$ Vezir Ali b. İsâ'nın takdir ve sevgisin kazanan Ebû Ömer, Bağdat'ta çok büyük vakar ve şöhrete sahip olmuştur. Oğlu Ebu'l-Hüseyin de daha sonraki zamanda kadı olarak görev yapmıştır. ${ }^{85}$

243/857 yılında Basra'da doğan Ebû Ömer, babası Kadı Yûsuf b. Yakup'tan ilim tahsil etmiş ve hadis rivayetinde bulunmuştur. Dârekutnî gibi bazı hadis âlimleri Ebû Ömer'i sika kabul etmiş ve ondan hadis

79 Tenûhî, Nişvârü'l-muhâdara, 1/22, 41.

80 İbnü'l-Cevzî, el-Muntazam, 13/200; İbn Kesîr, el-Bidâye ve'n-nihâye, 14/818.

81 Zehebî, Siyeru a'lâmi’l-nübelâ, 11/157, 203; Zehebî, el-'Tber fî̀ haberi men ğaber, 1/453; Massignon, İslâm'ın Mistik Şehidi, 1/140.

82 Câmî, Nefahâtü'l-üns, 280; Mustafâ b. Abdullah el-Osmânî Kâtib Çelebî, Süllemü'lvusûl ilâ tabakâti'l-fuhûl, thk. Mahmûd Abdülkâdir el-Arnâvûd (İstanbul: Mektebetü İrsîkâ, 2010), 1/214.

83 Câmî, Nefahâtü'l-üns, 281;

84 Ebû Bekir Muhammed b. Halef el-Vekî‘, Ahbâru'l-kudât, thk. Abdülaziz Mustafa elMurâğ̂̂i (Misır: el-Mektebetü't-ticâriyyeti'l-kübrâ, 1366/1947), 3/280-283; İbnü'lCevzî, Telbîsü İblîs, 154; Ebû İshâk eş-Şîrâzî, Tabakâtü'l-fukahâ, thk. İhsân 'Abbâs (Beyrût: Dârü'r-râidi'l-'Arabî, 1970), 165; Zehebî, Târîhu'l-İslâm, 23/8; İbnü'l-Verdî, Târîhu İbnü'l-Verdî, 1/248;

85 Şîrâzî, Tabakâtü'l-fukahâ, 165; Zehebî, Târîhu'l-İslâm, 23/8; İbnü'l-Verdî, Târîhu İbnü'l-Verdî, 1/248. 
ahzinde bulunmuşlardır. Hilim, zekâ ve akıl yönünden güçlü kabul edilen Ebû Ömer, Halife Muktedir-Billâh tarafından 317/929 yılında makam terfi ettirilerek Abbasî Devleti'nin 'Kâdı'l-kudât'ık yani baş kadılık makamına getirilmiştir. Üç yıl Kâdı'I-kudât olarak görev ifa eden Ebû Ömer, 320/932 senesinde vefat etmiştir. ${ }^{86}$

\section{Ebû Muhammed el-Cerirî (ö. 321/933):}

Hallâc'ın küfrüne ve katline fetva verenlerden birisi de Ebû Muhammed el-Cerirî́dir. Cerirî bu fetvayı Vezir Hâmid'in isteği doğrultusunda mahkeme önüne şâhit olarak çıkarıldığında vermiştir. Cüneyd-i Bağdâdî'nin en gözde talebelerinden birisi olan Ebû Muhammed el-Cerirî́ye mahkemede Hallâc'ın Mine'r-Rahmâni'r-Rahîm ilâ fulân b. fülân adlı eseri hakkındaki kanaatı sorulmuş, Cerîrî de: "Bu kitabı yazanın öldürülmesi gereken bir kâfir olduğunu ifade etmiştir. ${ }^{87}$

Cerirî'nin bu fetvayı Vezir Hâmid'den çekinerek vermiş olma ihtimali kuvvetlidir. Çünkü Cerirî ile aynı zamanda şâhit olarak çağrılan ibn 'Atâ vezirin istediği sözü söylemediği için işkence yapılarak öldürülmüştür. ${ }^{88}$

'Amr b. Osman el-Mekkî (ö. 296/909):

Hallâc'ın küfrüne fetvâ veren şahıslardan birisi de 'Amr b. Osman elMekkî'dir. 'Amr b. Osman Hallâc'ın hocasıdır. Hallâc tasavvuf hırkasını 'Amr b. Osman'dan giymiştir. Sûfîlerin şeyhi olan 'Amr b. Osman fıkıhta da imam kabul edilmektedir. Cidde'ye bir kadı olarak atandığında Cüneydi Bağdâdî onu terk etmiştir. ${ }^{89}$

'Amr b. Osman'ın Hallâc'a küfürle ithamı iki sebebe dayanmaktadır. Onlardan birisi 'Amr b. Osman bir seferinde Kur'an okur. Yanında bulunan Hallâc: "Ben de bunun gibisini söyleyebilirim der." 'Amr b. Osman, Hallâc'ın bu sözünden dolayı Kur'ân'ı tahkir ettiği suçlamasıyla onu küfürle itham etmiş ve "Gücüm yetse seni ellerimle öldürürüm demiştir."

'Amr b. Osman'ın Hallâc'a kızmasının bir diğer sebebi de tasavvuf ilmine dair yazdı̆̆ı bir kitabını Hallâc'ın çaldığına kani olmasındandır. Bunun üzerine 'Amr b. Osman: "Allahım! Sen ona öyle bir kimseyi mu-

86 Bağdâdî, Târîhu Bă̆dâd, 4/635, 11/284; Zehebî, Siyeru a'lâmi'l-nübelâ, 11/339-340.

87 Bağdâdî, Târîhu Bağdâd, 8/706; Zehebî, Siyeru a lâmi'l-nübelâ, 11/203; İbn Kesîr, elBidâye ve'n-nihâye, 14/831; 'Askalânî, Lisânü'l-mîzân, 3/212.

88 Bağdâdî, Târîhu Bağdâd, 8/706; İbnü'l-Cevzî, Telbîsü İblîs, 154; 'Askalânî, Lisânü'lmîzân, 3/212.

89 Zehebî, Siyeru a'lâmi'l-nübelâ, 11/38.

90 İbnü'l-Cevzî, Telbîsü İblîs, 153; İbnü'l-Cevzî, el-Muntazam, 13/203; İbn Teymiyye, elFetâvâ el-Kübrâ, 3/482; 'Askalânî, Lisânü'l-mîzân, 3/211. 
sallat et ki, ellerini ayaklarını kessin, gözlerini oysun, darağacına çeksin" demiştir. ${ }^{91}$ Abdurrahman Câmî'ye göre Hallâc'ın katledilmesinin gerçek sebebi üstadı 'Amr b. Osma'ın bedduasını almış olmasıdır. ${ }^{92}$

Ebû Bekir Muhammed b. Dâvud (ö. 297/910)

Hallâc'ın katline fetva verdiği söylenen bir şahıs da Ebû Bekir Muhammed b. Dâvud'dur. Muhammed b. Dâvud, zamanın önde gelen âlimleri arasında kabul edilmektedir. Ferâiz ve ez-Zehra fi'l-âdâb ve diğer başka eserlerin müellifi olan Muhammed b. Dâvud, Zâhirî mezhebinin kurucusu Dâvûd ez-Zâhirînnin (ö. 270/884) oğludur. Muhammed b. Dâvud babasından sonra zâhiri mezhebinin ikinci imamı kabul edilmektedir. Yedi yaşında Kur'an hafızı olan Muhammed b. Dâvud, güzel ahlak ve cömertlik konularında ön plandadır. Muhammed b. Dâvud kırk üç yaşında 297/910 senesinde Ramazan ayında vefat etmiş̧ir. ${ }^{93}$

Muhammed b. Dâvud'un Hallâc karşıtlığı Hallâc'ın Bağdat'a gelip burada bir ev inşa edip insanları kendi görüşlerine davete kalkıştı̆̆ı zamana dayanır. Bu zamanda bir grup fukaha Hallâc'a karşı çıktığı gibi Muhammed b. Dâvud da Hallâca karşı cephe almıştır. ${ }^{94}$ Hallâc'a şiddetli tepki gösteren Muhammed b. Dâvud'un vefatından önce söylediği şu sözü meşhurdur: “Eğer Allah'ın Hz. Peygamber'ine (a.s.) indirdikleri haksa o zaman Hallâc'ın dedikleri tamamen bâtıldır." ${ }^{95}$

Abdülkâhir el-Bağdâdî, el-Fark beyne'l-fırak adlı eserinde Muhammed b. Dâvud'un Hallâc'ın katline fetva verdiğini açıkça beyan etmektedir. ${ }^{96}$ Ancak Muhammed b. Dâvud'un 297/910 olan vefat tarihi düşünüldüğünde bu bilgilerin Hallâc'ın nihâî mahkemedeki durumuyla ilgili olmadığı âşikardır. Bağdâdî'nin verdiği bilginin Muhammed b. Dâvud'un vefat tarihini düşünerek 297/910 yılından öncesine ait olduğunu söylemek gerekir. Bağdâdî dışındaki diğer bazı kaynaklarda ise Muhammed b. Dâvud'un Hallâc'ın küfür ve zındıklığına fetva verdiği değil daha çok Hallâc'ın davranışlarını eleştirdiği ve onları kabih gördüğü şeklindedir. ${ }^{97}$

Cüneyd-i Bağdâdî (ö. 297/909):

91 Zehebî, Siyeru a'lâmi'l-nübelâ, 11/195; Câmî, Nefahâtü'l-üns, 292.

92 Câmî, Nefahâtü'l-üns, 292.

93 Zehebî, Siyeru a'lâmi'l-nübelâ, 10/276-277.

94 Zehebî, Târîhu'l-ìslâm, 23/34; Zehebî, Siyeru a lâmi'l-nübelâ, 11/200.

95 Bağdâdî, Târîhu Bağdâd, 8/707; Sem'ânî, el-Ensâb, 4/317; Zehebî, Siyeru a'lâmi'lnübelâ, 11/203; İbnü'l-Cevzî, Telbîsü İblîs, 155; Massignon, İslâm'ın Mistik Şehidi, $1 / 45$.

96 Bağdâdî, el-Fark beyne'l-firak, 247.

97 Sem'ânî, el-Ensâb, 4/317; İbn Hallikân, Vefayâtü'l-a'yân, 2/142. 
Ferîdüddîn Attâr, Tezkiretü'l-Evliyâa adlı eserinde Hallâc'ın katline fetva verenlerden birinin de Cüneyd-i Bağdâdî olduğunu beyan etmektedir. Attâr'ın beyanına göre fukahânın Hallâc'ın katledilmesine dâir fetva verdikleri gün sûfî kisvesinde olan Cüneyd, fetva verip karara imza koymak istememiştir. Ancak Halife'nin, Cüneyd'in fetvası da lazım diye emretmesi üzerine Cüneyd sûfî kisvesini çıkararak, zâhir âlim kisvesini giymiş: "Biz zâhire göre hükmederiz, fetva zahir üzerinedir, ancak bâtını Allah bilir" diyerek Hallâc'ın katline fetvasını yazmıştır. ${ }^{98}$

Hem Muhammed Parsâ hem de Abdurrahman Câmî Attâr'ın görüşüne katılmamaktadırlar. Onlara göre Cüneyd'in Hallâc'ın katline fetva verdiğine dair sözleri tamamen uydurma ve iftiradır. Onlar bu hususu ifade ederken Hallâc'ın vefat tarihi ile Cüneyd'in vefat tarihine dikkat çekmektedir. Ona göre 297/910 tarihinde vefat eden Cüneyd'in kendisinden on bir yıl sonra vefat eden Hallâc'ın katline fetva vermesi mümkün değildir. ${ }^{99}$ Cüneyd'in Hallâc'ın katline fetva vermese de Hallâc' ı 'iddiâ' ve 'bid'at' ehli olmakla suçlaması ve ona: 'Kanın hangi darağacını ıslatacak' dediği malumdur. ${ }^{100}$ Bazı müellifler ise Parsâ ve Câmî'nin aksine hem Cüneyd hem de Muhammed b. Dâvudu'n nihaî mahkemede değil daha önceki mahkemeler için Hallâc'ın katline fetva vermelerini mümkün görmektedir. ${ }^{101}$

\title{
Sonuç
}

Hallâc'ın 244/858 yılında İran'ın büyük şehirlerinden Beydâ'da başladığı hayatı atmış beş yıl sonra Bağdat'ta nihayete ermiştir. Hallâc birçok beldeyi dolaşmış, buraların ilim ve kültüründen istifade etmiştir. Hallâc'ın hayatında ikinci Hindistan seferi dönüm noktası olmuştur. Hallâc'ın biyografisini yazan müellifler ikinci Hindistan seferini kıstas alarak Hallâc'ın hayatı hakkında öncesi ve sonrası olmak üzere iki döneme işaret etmektedirler.

Hallac'ın ilk dönem hayatı fukahanın tepkisini çekebilecek sözlerden uzak, zühd ve ibadet ağırlıklı olarak geçmiştir. Bu dönemde Hallâc, Sehl b. Abdullah et-Tüsterî, Ebü'I-Kâsım Cüneyd-i Bağdâdî, Ebü'l-Hüseyin enNûrî ve 'Amr b. Osman el-Mekkî gibi meşhur sufîlerin yanında bulunmuş ve onların manevî neşvelerinden istifade etmiştir. İkinci Hindistan sefe-

\footnotetext{
98 Attâr, Tezkiretü'l-Evliyâ, 706.

99 Parsâ, Tevhîde Giriş, 92; Câmî, Nefahâtü'l-üns, 290.

100 Bağdâdî, Târîhu Bağdâd, 8/690; Sem‘ânî, el-Ensâb, 4/316; Zehebî, Siyeru a'lâmi’lnübelâ, 11/195-196.

101 Yâfi'î, Mirâtü'l-cenân, 2/194.
}

\author{
$\mathrm{db} \mid 1189$
}


rinden sonra ise Hallâc'ın hayatında yeni bir dönem başlamıştır. Bu dönemdeki söz ve fiillerinden dolayı Hallâc, fukahânın sert tepkisiyle karşılaşmış ve bu dönemde aleyhinde konuşmalar çoğalmaya başlamıştır.

Bu ikinci döneminde maruz kaldığı ithamlar neticesinde Hallâc, 299/911, 301/913 ve nihai tarih 309/922 olmak üzere üç mahkeme sürecinde sorgulanmış ve yargılanmıştır. Hayatının son dokuz yılını hapishanede tutuklu olarak geçiren Hallâc, nihaî mahkemenin sonucunda küfür ve zındıklık suçlamasıyla katl cezasına mahkûm edilmiş ve hüküm de o şekilde infaz edilmiştir.

Üç mahkemenin hemen hemen hepsinde Hallâc'a Karâmita mensubiyeti suçlamasının yanı sıra, hulûl, ittihat, rubûbiyyet, Kur'ân'ı tahkir ve şeri'atın emirlerini tahrif ve tebdil suçlamaları da yöneltilmiştir. Ancak bu mahkeme süreçlerinde aleyhine delil olarak 'Ene'l-Hak' sözü gündeme gelmemiştir.

Hallâc, hulûl, ittihat ve rubûbiyyet iddiasıyla kendisine yöneltilen hiçbir suçlamayı kabul etmemiş ve kendi hâlinin 'aynü'l-cem' olduğunu beyan etmiştir. Mahkemenin Hallâc'a verdiği idam cezasında Hallâc'ın hac konusundaki görüş ve düşünceleri esas gerekçe olmuştur. Bu manada Hallâc, hac konusundaki düşüncelerinden yani dinin rükunlarını tahrif ve tebdil suçlamasından dolayı ceza almıştır. Hayatında üç kere hac görevini ifa eden bir şahsa hac konusunda tahrif ve tebdil suçlamasının yöneltilmesi ve cezanın da ana gerekçesinin bu suçlamanın olması düşündürücüdür.

Hallâc hakkında katl kararının alınmasında Vezir Hamîd'in ısrarı ve mahkeme heyetine baskısı ve yönlendirmesi etkili olmuştur. Kaynaklarda Hallâc'ın katli konusunda ulemanın ittifak ve icmâı olduğu belirtilmektedir. Ancak Ebû Ca'fer Ahmed b. İshâk b. el-Bühlûl, Ebü'l-'Abbâs Ahmed b. Muhammed b. 'Atâ ve Ebü'I-Abbâs Ahmed b. Ömer b. Süreyc el-Bağdâdî gibi önemli isimler bu ittifaka dâhil olmamışlar ve verilen karara katılmamışlardır. Bu durum ittifak ve icmâ iddialarının varlığını şüpheye düşürmektedir.

Hallâc'ın katline fetva ve karar veren iki isim net olarak bilinmektedir. Bunlardan birisi Vezir Hâmid diğeri ise, Kadı Ebû Ömer Muhammed b. Yûsuf'dur. Bunlar dışında nihai mahkemede fetva veren karara imza atan isimleri net bilmek mümkün değildir. Cüneyd-i Bağdâdî ve Ebû Bekir Muhammed b. Dâvud'un Hallâc'ın katline fetvâ verdikleri husus tartışmaIıdır. Bazıları bu iki şahsın vefat tarihine bakarak Hallâc'ın katline fetva vermelerini mümkün görmezken diğer bazıları ise nihaî mahkeme için 
değil daha önceki mahkeme süreçlerine dikkat çekerek bunu mümkün görmektedirler.

\section{KAYNAKÇA}

'Âmilî, Bahâeddîn Muhammed b. Hüseyin. el-Keşkûl. thk. Muhammed Abdülkerîm en-Nemirî. 2 cilt. Beyrût: Dârü'l-kütübi'l-ilmiyye, 1418/1998.

'Askalânî, Ebü'l-Fadl Ahmed b. Ali İbn Hacer. Lisânü'l-mîzân. nşr. Abdülfettah Ebû Ğudde. 10 cilt. Dımaşk: Dârü'l-beşâiri'l-İslâmiyye, 2002.

Attâr, Ferîdüddin. Tezkiretü'l-Evliyâ. çev. Süleyman Uludağ. İstanbul: Semerkand Yayınları, 2018.

Bağdâdî, Ebû Bekir Ahmed b. Ali el-Hatîb. Târîhu Bağdâd. thk. Beşşâr 'Avvâd Ma'rûf. 16 cilt. Beyrût: Dârü'l-ğarbi'l-i̇slâmî, 1422/2002.

Bağdâdî, Ebû Mansûr Abdülkâhir b. Tâhir. el-Fark beyne'l-fırak ve beyânü'l-fırkati't-nâciye. Beyrût: Dârü'l-âfâkı'l-cedîde, 1977.

Bakış, Rıza. Âşığın Tevhîdi. İstanbul: İnsan Yayınları, 2013.

Câmî, Abdurrahman. Nefahâtü'l-üns. çev. Lâmiî Çelebi. Nşr. Süleyman Uludağ, Mustafa Kara. 4. Baskı. İstanbul: Marifet Yayınları, 2008.

Dârekutnî, Ebü'l-Hasan Ali b. Ömer. Sünenü'd-Dârekutnî. thk. Şuayb el-Arnavûd, Hasan Abdülmün'ım Şiblî. 5 cilt. Beyrût: Müessesetü'r-risâle, 1424/2004.

Ebû Dâvud, Süleymân b. el-Eş'as. Sünenü Ebî Dâvud. İstanbul: Çağrı Yayınları, 1992.

Gazzâlî, Ebû Hâmid. Mişkâtü'I-envâr. nşr. Ebu'I-'Alâ 'Afîfî. Kahire: el-Mektebetü'I-'Arabiyye, $1383 / 1964$.

Hücvirî, Ali b. Osman Cüllâbî, Keşfu'l-mahcûb (Hakikat Bilgisi). nşr. Süleyman Uludağ. İstanbul: Dergâh Yayınları, 2010.

İbn Hallikân, Ebu'l-Abbâs Şemsüddîn Ahmed b. Muhammed. Vefayâtü'l-a'yân ve enbâu ebnâi'zzamân. nşr. İhsân Abbâs. 7 cilt. Beyrut: Dâru Sâdır, 1994.

İbn Kesîr, Ebû'l-Fidâ İsmail b. Ömer. el-Bidâye ve'n-nihâye. nşr. Abdullah b. Abdulmuhsin etTürkî. 21 cilt. Kâhire: Dâru hecr, 1418/1997.

İbn Miskeveyh, Ebû Ali Ahmed b. Muhammed. Tecâribü'l-ümem ve te 'âkıbü'l-himem. thk. Ebü'lKâsım İmâmî. 7 cilt. Tahrân: Serûş, 2000.

İbn Teymiyye, Ebû'l-'Abbâs Takıyüddîn Ahmed b. Abdülhalîm. el-Fetâvâ el-Kübrâ. thk. Muhammed Abdülkâdir 'Atâ, Mustafa Abdülkâdir 'Atâ. 6 cilt. Beyrût: Dârü'l-kütübi'l-ilmiyye, $1408 / 1987$.

İbn Teymiyye, Ebû'l-'Abbâs Takıyüddîn Ahmed b. Abdülhalîm. Mecmû'u'l-fetâvâ. nşr. Enver elBâz, 'Âmir el-Cezzâr 37 cilt. Mısır: Dârü'l-Vefâ, 1426/2005.

Ibnü'l-Esîr, Ebü'l-Hasan Ali b. Ebî'l-Kerem el-Cezerî. el-Kâmil fi't-târîh. thk. Ömer Abdüsselâm Tedmirî. 10 cilt. Beyrût: Dârü'l-kitâbi'l-'Arabî, 1417/1997.

İbnü'I-Esîr, Ebü'l-Hasan Ali b. Ebî’l-Kerem el-Cezerî. el-Lübâb fî tehzîbi'l-ensâb. Beyrût: Dâru Sâdır, 1400/1980.

Ibnü'n-Nedîm, Ebü'l-Ferec Muhammed b. İshâk. el-Fihrist. thk. İbrâhim Ramazân. Beyrût: Dârü'lma'rife, 1417/1997.

İbnü'l-Tıktakâ, Muhammed b. Ali. el-Fahrî fi'l-âdâbi'l-sultâniyye ve'd-düveli'l-islâmiyye. thk. Abdülkâdir Muhammed Mâyû. Beyrût: Dârü'l-kalemi'l-'Arabî, 1418/1997.

İbnü'I-Verdî, Zeynüddîn Ömer b. Muzaffer. Târîhu ibnü'l-Verdî. 2 cilt. Beyrût: Dârü'I-kütübi'lilmiyye, 1417/1996.

İbnü'I-Cevzî, Ebü'l-Ferec Cemâleddin Abdurrahmân b. Ali. el-Muntazam fîtârîhi'l-ümemi ve'lmülûk. nşr. Muhammed Abdülkadir 'Atâ ve Mustafa Abdülkadir 'Atâ. 19 cilt. Beyrût: Dâru'l-kütübi'l-ilmiye, 1412/1992.

İbnü'I-Cevzî, Ebü'l-Ferec Abdurrahman b. Ali. Telbîsü Iblîs. Lübnân: Dârü'l-fikir, 1421/2001.

Kadı 'Iyâd, Ebü'l-Fadl b. Mûsâ, eş-Şifâ bi ta'rîfi hukûkı'l-Mustafâ. thk. Ahmed b. Muhammed eşŞemnî. 2 cilt. Lübnân: Dârü'l-fikir, 1409/1988. 
Kâtib Çelebî, Mustafâ b. Abdullah el-Osmânî. Süllemü'I-vusûl ilâ tabakâti'l-fuhûl. thk. Mahmûd Abdülkâdir el-Arnâvûd. 6 cilt. ìstanbul: Mektebetü İrsîkâ, 2010.

Kuşeyrî, Abdülkerîm b. Hevâzin. Letâifü'I-işârât (Tefsîru'I-Kuşeyrî). thk. İbrâhim el-Bisyûnî. 3 cilt. Mısır: el-Heyetü'l-Mısriyyeti'l-'âmme li'l-kütüb, 2000.

Massignon, Louis. İslâm'ın Mistik Şehidi Hallâc-ı Mansûr'un Çilesi. çev. issmet Birkan Ankara: Ardıç Yayınları, 2006.

Parsâ, Hâce Muhammed. Tevhîde Giriş. çev. Ali Hüsrevoğlu. İstanbul: Erkam Yayınları, 2018.

Sâ'î, Ali b. Enceb el-Bağdâdî. Ahbâru'l-Hallâc. thk. Muvaffık Fevzî el-Ceber. Dımeşk: Dârü'ttalî'ati'l-cedîde, 1997.

Safedî, Salâhaddîn Halîl. el-Vâfi bi'l-vefeyât. thk. Ahmed el-Arnavud, Türkî Mustafa. 29 cilt. Beyrût: Dâru ihyâi't-türâs, 1420/2000.

Sem'ânî, Ebû Sa'îd Abdülkerîm b. Muhammed b. Mansûr. el-Ensâb. nşr. Abdurrahmân b. Yahyâ. 13 cild. Haydarâbâd: Meclis-i dâireti'l-meârifi'l-Osmâniyyi, 1382/1962.

Suyûtî, Ebû Bekir Abdurrahman. Târîhu'I-hulefâ. thk. Muhammed Muhyiddîn Abdulhamîd. Mısır: Matba'atü's-se'âde, 1371/1952.

Sülemî, Ebû Abdurrahmân Muhammed b. el-Hüseyin. Tabakâtü's-sûfiyye. thk. Nûreddîn Şûreybe. 4. Baskı. Kâhire: Mektebetü'l-Hâncî, 1434/2014.

Sülemî, Ebû Abdurrahmân Muhammed b. el-Hüseyin. Hakâiku't-tefsîr (Tefsîru's-Sülemî). thk. Seyyid 'Imrân. 2 cilt. Beyrût: Dârü'l-kütübi'I-ilmiyye, 1421/2001.

Şîrâzî, Ebû İshâk. Tabakâtü'l-fukahâ. thk. İhsân 'Abbâs. Beyrût: Dârü'r-râidi'l-'Arabî, 1970.

Taberî, Ebû Ca'fer Muhammed b. Cerîr. Târîhu'l-ümem ve'l-mülûk (Târîhu't-Taberî). 5 cilt. Beyrût: Dârü'l-kütübi'l-ilmiyye, 1407.

Tenûhî, Ebû Ali el-Muhassin b. Ali el-Kadı. Nişvârü'I-muhâdara ve ahbâru'l-müzâkere. Thk. Abbûd es-Sâlucî. 8 cilt. Beyrût: Dâru Sâdır, 1995.

Tirmizî, Ebû Îsâ Muhammed b. Îsâ. Sünenü't-Tirmizî. 4 cilt. İstanbul: Çağrı Yayınları, 1413/1992.

Uludağ, Süleyman. "Hallâc-ı Mansûr", Türkiye Diyanet Vakfı İslâm Ansiklopedisi, 15/377-381. İstanbul: TDV Yayınları, 1997.

Vekî', Ebû Bekir Muhammed b. Halef. Ahbâru'l-kudât. thk. Abdülaziz Mustafa el-Murâğî. 3 cilt. Mısır: el-Mektebetü't-ticâriyyeti'l-kübrâ, 1366/1947.

Yâfi'î, Ebû Muhammed 'Afiffüddîn Abdullah b. Es'ad. Mirâtü'I-cenân ve 'ibretü'l-yakazân. nşr. Halîl el-Mansûr. Beyrut: Dârü'l-kütübi'l-ilmiyye, 1417/1997.

Zehebî, Ebû Abdillâh Şemsüddîn Muhammed b. Ahmed. Siyeru a'lâmi'l-nübelâ. 18 cilt. Kâhire: Dâru'l-hadîs, 1427/2006.

Zehebî, Ebû Abdillah Muhammed b. Ahmed. el-'lber fî haberi men ğaber. thk. Ebû Hacer Muhammed es-Saîd. 4 cilt. Beyrût: Dârü'I-kütübi'l-ilmiyye, 1985.

Zehebî, Ebû Abdillâh Şemseddin Muhammed b. Ahmed. Târîhu'I-Islâm ve vefayâtü'l-meşâhir ve'l-e'lâm. nşr. Ömer Abdüsselam Tedmirî. Beyrut: Dârü'I-kitâbi'I-'Arabî, 1407/1987. 


\section{The Court Process of Hallac and Those Who Gave Fatwa of the Death Penalty}

Eyyup AKDAĞ *

\section{Extended Abstract}

Hallac was born in Beyda, one of the major cities of Iran, in 244/858 and he passed away in Baghdad 65 years later. Hallac traveled to many towns and benefited from the science and culture of these places. The second Indian expedition was the turning point in Hallac's life. The authors, who wrote the biography of Hallac, point out two periods of his life by taking before and after the second Indian expedition as a criterion.

The first stage of Hallac's life was far from words that could attract the reaction of the canonist, and he mainly lived with asceticism and worship. In this period, Hallac was with the famous Sufis like Sehl b. Abdullah et-Tusteri, Ebu'I-Kasim Cuneyd-i Bagdadi, Ebu'l-Huseyın en-Nuri, 'Amr b. Osman el-Mekki and benefited from their spiritual joy. After the second Indian expedition, a new era started in Hallac's life. Due to his words and actions during this period, Hallac faced the harsh reaction of the canonist, and speeches against him started to increase in this period.

As a result of the accusations he suffered in this second period, Hallac was questioned and put on trial in three judicial processes dating 299/911, 301/913 and the final date was $309 / 922$. Spending the last nine years of his life in prison as a prisoner, Hallac was sentenced to death with the charges of profanity and atheism as a result of the final court, and the sentence was executed in that way.

In almost all of the three courts, aside from accusation of being a member of Karamite, Hallac was also charged with integration (hulul), unification (ittihat), nursing (rububbiyyet), insulting the Qur'an, and falsification and amendment of the orders of the Sharia. However, the word 'Ene'I-Hak' ('I am one with God') was not brought into as evidence against him this court process.

Hallâc did not accept any accusations against him on integration (hulul), unification (ittihat), nursing (rububbiyyet), and declared that his condition was 'aynu'l-cem' (free of living separately with God). In the death penalty given by the court to Hallac, Hallac's views and thoughts on pilgrimage was the main reason. In this sense, Hallac was punished for his thoughts on the pilgrimage, namely the falsification and amendment of elements of religion. It is thought-provoking that the accusation of falsification and amendment is directed to the person, who performed the pilgrimage duty three times in his life, and the main reason for the punishment is this accusation.

\footnotetext{
Assistant Professor, PhD, Kastamonu University, Faculty of Theology, Department of Sufism, Kastamonu/Turkey, eyyupakdag5@hotmail.com, Orcid Id: https://orcid.org/0000-0002-1173-323X
} 
The insistence of Vizier Hamid and the pressure and direction of the court committee was effective in the decision of the death penalty of Hallac. The sources state that the death penalty of Hallac is due to the alliance and consensus of the ulama. However, important names such as Ebu Ca'fer Ahmed b. Ishak b. el-Buhlul, Ebu'l-'Abbas Ahmed b. Muhammed b. 'Ata ve Ebu'l-Abbas Ahmed b. Omer b. Sureyc el-Bagdadi did not belong to this alliance and did not agree with the decisions given. This situation brings the existence of alliance and consensus claims into doubt.

The names of two people who gave fatwa and decision on the death penalty of Hallac are clearly known. One of them is Vizier Hamid and the other one is Kadi Abu Omer Muhammed b. Yusuf. Apart from these, it is not possible to know the names that signed the decision giving fatwa in the final court. The subject that Cuneyd-i Bagdadi and Ebu Bekir Muhammed b. Davud gave fatwa of the death penalty of Hallac is controversial. Some do not consider it possible to give fatwa of the death penalty of Hallac because of their date of death, while others consider it possible drawing attention to previous court processes, not the final court.

Keywords: Sufism, Hallac, Court process, Fatwa, Profanity, Slaughter.

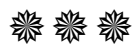

$1194 \mid \mathrm{db}$ 